\title{
胎児性胆汁酸及び関連ステロイドの高性能分析法の開発と体内動態の解析
}

\author{
藤間貞彦
}

北海道医療大学薬学部， $\overline{\mathbf{T}} 061-02$ 北海道石狩郡当別町金沢 1757

\section{Determination of Fetal Bile Acids and Related Steroidal Compounds and Their Profile in Neonatal Biological Fluids}

\author{
Masahiko ToHMA \\ Faculty of Pharmaceutical Sciences, Health Sciences \\ University of Hokkaido, Ishikari-Tobetsu, \\ Hokkaido 061-02, Japan
}

(Received June 13, 1996)

The unusual bile acids hydroxylated at $1 \beta-, 2 \beta-, 4 \beta-, 6 \alpha$ - and 19-positions of cholic and chenodeoxycholic acids have been found from the meconium, neonatal bile, blood and urine, and amniotic fluid and pregnant urine by GC-MS analysis. These hydroxylated bile acids and their conjugates were synthesized as their references from the corresponding usual bile acids as starting materials, and the simultaneous and high performance analytical methods were developed by GC-MS, HPLC and enzyme immunoassay. The above mentioned unusual bile acids were identified and determined in significant amounts of the total bile acids in the biological fluids from neonates and pregnant women, but not from normal adults. We, therefore, proposed that they should be called as "fetal bile acids". Application of the developed methods was performed for the studies on the dynamic profile of fetal bile acids in developing fetus and neonates, and the clinical diagnosis of the hepatobiliary diseases of infants and congenital bile acid biosynthetic disorders, Zellweger syndrome, celebrotendinus xanthomatosis, 3 -oxo- $\Delta^{4}$-steroid $5 \beta$-reductase deficiency and congenital biliary atresia. Analyses of steroidal hormones, equine estrogens and 18-hydroxycortisol were also described.

Key words —- fetal bile acid; gas chromatography-mass spectrometry; highperformance liquid chromatography; enzyme immunoassay; neonatal bile acid biosynthesis; congenital hepatobiliary disorder

\section{はじめに}

胆汁酸は肝臟においてコレステロールより生合成されるステロイドの一群であり，古くより 肝機能の診断指標として注目されてきた．生体内の複雑なマトリックス中にはこの他にも極め て微量のステロイドホルモンが多岐に亘り混在し，それぞれが特異的な生理活性を示すので, これらの量論的研究には，高感度，特異的，選択的な高性能一斉分析法が必要であり，臨床医 学の研究ではさらに迅速性も要求されている. しかし，これらの生体成分に関する研究の险路

本総説は，平成 7 年度日本薬学会学術貢献賞の受賞業績を中心に記述したあのである. 
は新規ステロイドの標品の入手にあり，これに基づいてはじめて高性能分析法の確立が達成さ れる. 今回の受賞対象は「生体内微量ステロイドの高性能分析法の開発之臨床化学への応用」 であるが，本稿では，最近の胎児性胆汁酸に関する研究を中心に概説することとした．

\section{1. 胎児性胆汁酸の分析之新生児肝胆道疾患の病態解析}

近年，種々の先天性肝胆道疾患（胆道閉鎖症，脳腱性黄色腫症，及び Zellweger, Allagille, Reye の各症侯群等）が見出され，これらの疾患の早期における診断法並びに治療法の確立が緊 急の課題となっている：胆汁酸は肝臟においてコレステロールよりステロイド骨格の水酸化や 酸化還元を経たのち，側鎖が酸化切断されて $\mathrm{C}_{24}$ 胆汁酸のコール酸 $(\mathrm{CA})$ 及びケノデオキシ コール酸 (CDCA) が生合成される (Fig. 1)。これらは胆管を経て十二指腸に排泄され，脂質の 消化・吸収に関係しているが，小腸から再吸収されて門脈を通り肝藏に戻る腸肝循環を行って いる.この際，これらの胆汁酸は腸内細菌により $7 \alpha$-位の水酸基が脱離されて，それぞれ二次胆 汁酸としてデオキシコール酸 (DCA) 及びリトコール酸 $(\mathrm{LCA})$ となり，健常成人体液中の主 要常成分として存在する. 胆汁酸の組成比には生合成の各段階における多数の酵素が関与して いるので, 胆汁酸は肝疾患における肝機能の診断指標として注目されてきた。しかし，ヒト体 液中には胆汁酸常成分の他に屯微量の異常胆汁酸が多種類存在し，さらに，それぞれの胆汁酸 はグリシン，タウリン及びサルフェートの抱合型として分布しているので，40 種以上に及ぶ各 成分を一斉に分析することは極めて困難である。したがって，近年，種々のクロマトグラ フィーによる分離分析法が開発されるまで微量胆汁酸の体内動態に関する研究は進展を見な

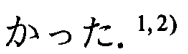

著者らは入戸野ら（順天堂大）との共同研究により，ヒトの胎児-新生児期の体液中には特異 な $1 \beta$-及び $6 \alpha$-水酸化胆汁酸が存在することを見出した。これらの新規異常胆汁酸の標品を化 学合成したのち，ガスクロマトグラフィ一質量分析 (GC-MS), 高速液体クロマトグラフィー (HPLC) 及び免疫学的測定法による微量分析法の開発を行った。 さらに，これらの分析法を用 いて胎児一新生児期における胆汁酸の体内動態について検討したところ，胎児一新生児体液中の 胆汁酸組成は成人の場合と大きく異なり，健常成人には見られない特異の胆汁酸が主要成分之 して存在するが，これらは発育に伴って減衰して幼児期には消失することが明らかになった。 したがって，これらの異常胆汁酸を「胎児性胆汁酸」として提唱し，分析化学並びに臨床化学 的研究を進めることとした。

現在, 小児肝胆道疾患における一般的肝機能検査は, 成人の場合と同様に総胆汁酸量を $3 \alpha-$ hydroxysteroid dehydrogenase を用いる酵素法により測定しているが，後述するように新生児期 には特異の胎児性胆汁酸が総胆汁酸量の 60-90\%を占めるので，この時期に胆汁酸を測定す る場合，この事実を無視することは臨床医学的にも重大な過誤となり，小児の発育に伴う胆汁 酸組成の変動並びに体内動態について早急に再検討することが必要となった。さらに，これら の新知見に基づいて，胎児性胆汁酸を指標とする先天性あるいは新生児肝胆道疾患の病態解析 法を開発し，新生児医療の発展に貢献することを研究の目的とした.

1-1. 胎児性胆汁酸の構造解析と微量定量法の開発 1) 新規胆汁酸の合成之同定一 Almé ${ }^{3}{ }^{3}$ Back $^{4}$ 並びに Strandwick ${ }^{5)}$ らの研究により胎児及び新生児体液（血液, 胆汁, 尿, 胎便 等) 中には，健常成人の場合と異なり異常な胆汁酸が多く存在することが予見されたので, GC-MS による構造解析を行った。 その結果, Fig. 1 に示すように新規 $1 \beta, 3 \alpha, 7 \alpha, 12 \alpha-$ (CA-1 $\beta$ ol), ${ }^{6,7)} 1 \beta, 3 \alpha, 7 \alpha$ - (CDCA-1 $\beta$-ol) 及び $3 \alpha, 6 \alpha, 7 \alpha, 12 \alpha$-水酸化胆汁酸 (CA-6 $\alpha$-ol $)^{8,9)}$ 並びに $3 \beta$ - $\left(\Delta^{5}\right.$ $3 \beta$-ol) 及び $3 \beta, 12 \alpha$-水酸化不飽和胆汁酸 $\left(\Delta^{5}-3 \beta, 12 \alpha \text {-diol }\right)^{10)}$ を胎便及び新生児尿から見出した. 


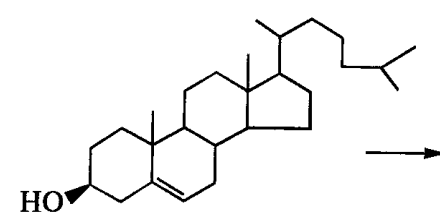

cholesterol

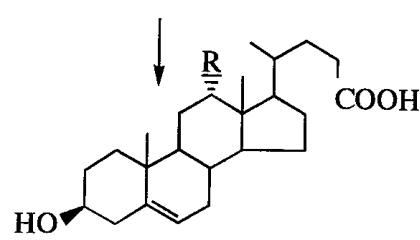

$\Delta^{5}-3 \beta, 12 \alpha$-diol : $\mathrm{R}=\mathrm{OH}$ $\Delta^{5}-3 \beta$-ol : R=H

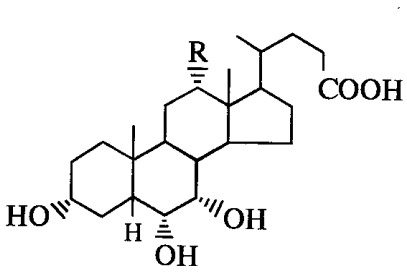

CA- $6 \alpha-\mathrm{ol}: \mathrm{R}=\mathrm{OH}$ $\mathrm{HCA}: \mathrm{R}=\mathrm{H}$

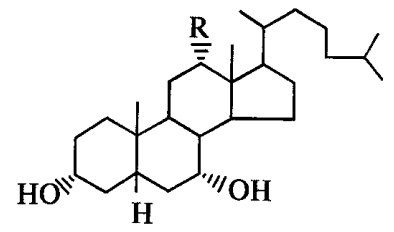

$\mathrm{R}=\mathrm{H}$ or $\mathrm{OH}$

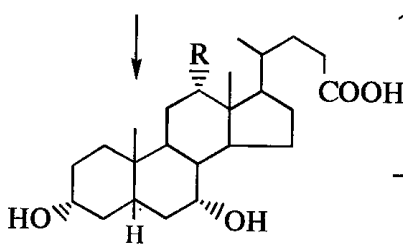

$\mathrm{CA}: \mathrm{R}=\mathrm{OH}$ CDCA : $\mathrm{R}=\mathrm{H}$

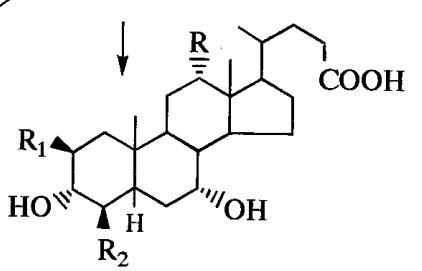

CA-2 $\beta-\mathrm{ol}: \mathrm{R}=\mathrm{R}_{1}=\mathrm{OH}, \mathrm{R}_{2}=\mathrm{H}$

CA-4 3 -ol : R=OH, $\mathrm{R}_{1}=\mathrm{H}, \mathrm{R}_{2}=\mathrm{OH}$

CDCA- $4 \beta$-ol : $R=\mathrm{R}_{1}=\mathbf{H}, \mathrm{R}_{2}=\mathrm{OH}$

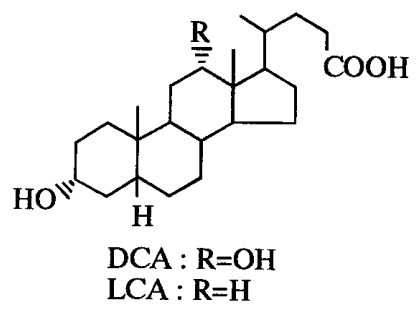

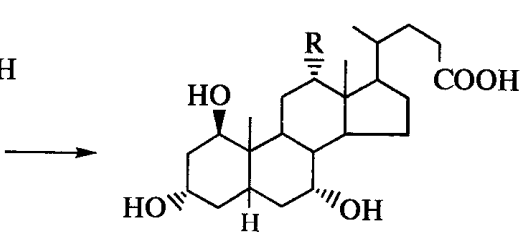

CA-1 $\beta$-ol : $\mathrm{R}=\mathrm{OH}$

CDCA-1 $\beta$-ol : $\mathrm{R}=\mathrm{H}$

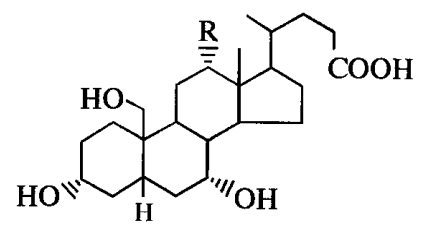

CA-19-ol : $\mathrm{R}=\mathrm{OH}$ CDCA-19-ol : $\mathrm{R}=\mathrm{H}$

Fig. 1. Postulated Pathways for the Biosynthesis of Fetal Bile Acids

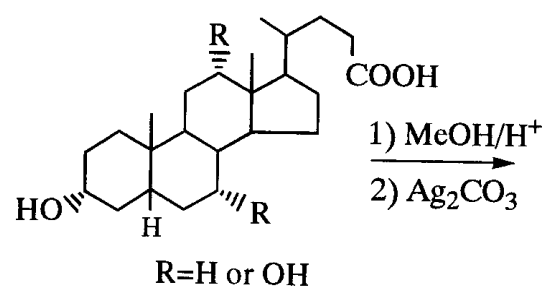

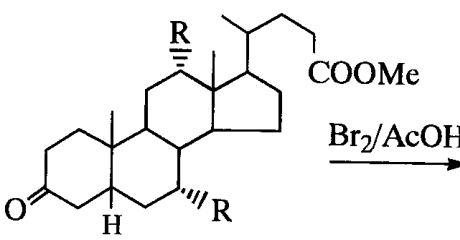

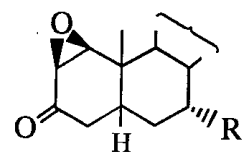<smiles>OO</smiles><smiles>[R]C1C[C@H]2CC(=O)C=CC2(C)C2CCC12</smiles>

$\stackrel{\mathrm{Zn} / \mathrm{AcOH}}{\longleftarrow}$<smiles>[R]C1C=CC2(C)C=CC(=O)C(Br)C2C1</smiles>

$\mathrm{Te} / \mathrm{NaBH}_{4}$<smiles>[R]C1C[C@H]2CC(=O)C[C@@H](O)[C@@]2(C)C(CC)C1C</smiles>

1) $\mathrm{NaBH}_{4} / \mathrm{AcOH}$

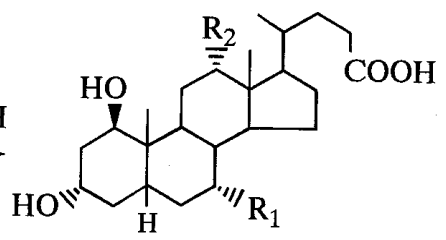

LCA- $1 \beta-$ ol : $\mathbf{R}_{1}=\mathbf{R}_{2}=\mathrm{H}$ DCA-1 $\beta$-ol : $\mathrm{R}_{1}=\mathrm{H}, \mathrm{R}_{2}=\mathrm{OH}$ CDCA-1 $\beta$-ol : $\mathrm{R}_{1}=\mathrm{OH}, \mathrm{R}_{2}=\mathrm{H}$ CA-1 $\beta$-ol : $\mathrm{R}_{1}=\mathrm{R}_{2}=\mathrm{OH}$

Fig. 2. Synthesis of $1 \beta$-Hydroxylated Bile Acids

またこれらの新規胆汁酸及び関連する胆汁酸の標品をそれぞれに胆汁酸常成分 CA 又は CDCA を出発原料として化学合成した. Fig. 2 に $1 \beta$-水酸化胆汁酸, Fig. 3 に $6 \alpha$-水酸化胆汁酸 の合成例を示す。

これらの標品はメチルエステル・トリメチルシリルエーテル誘導体として GC-MS における 


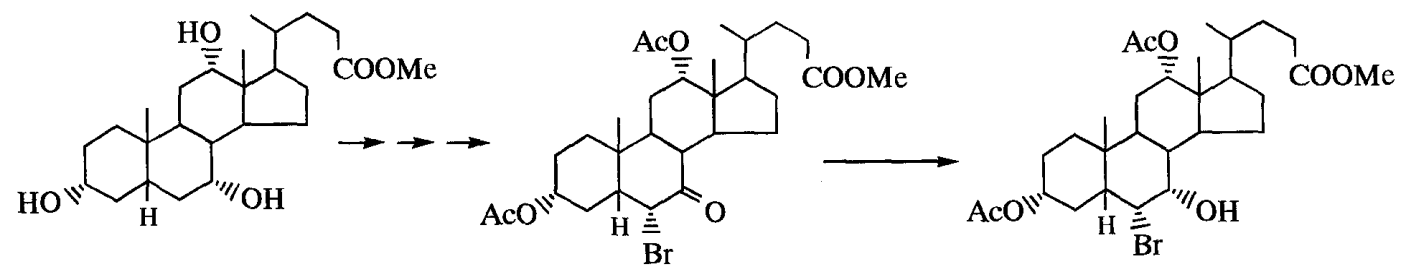

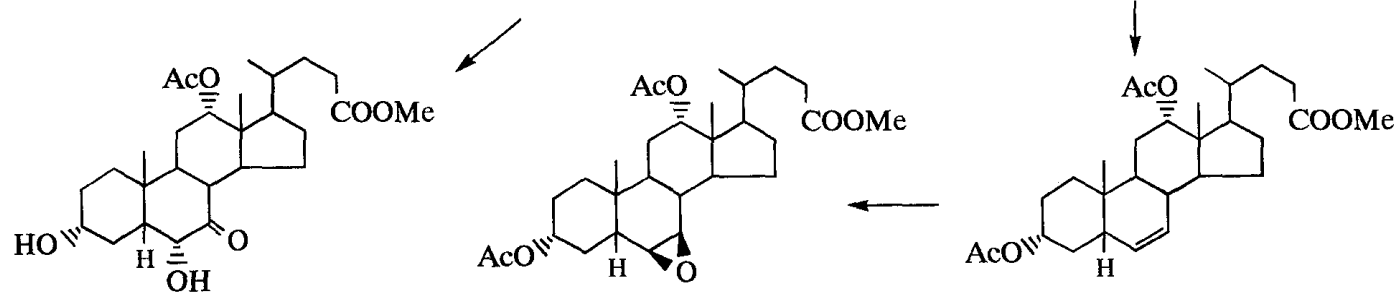<smiles>COC(=O)CCC(C)C1CCC2C3C(C[C@H](O)C12C)C1(C)CC[C@@H](O)C[C@H]1[C@H](O)[C@H]3O</smiles><smiles>CC(CCC(=O)O)C1CCC2C3C(C[C@H](O)C12C)C1(C)CC[C@@H](O)C[C@]1(C)[C@H](O)[C@H]3O</smiles><smiles>CC(CCC(=O)O)C1CCC2C3C(C[C@H](O)C12C)[C@]1(C)CC[C@@H](O)C[C@H]1[C@H](O)[C@H]3O</smiles>

Fig. 3. Synthesis of $6 \alpha$-Hydroxylated Bile Acids
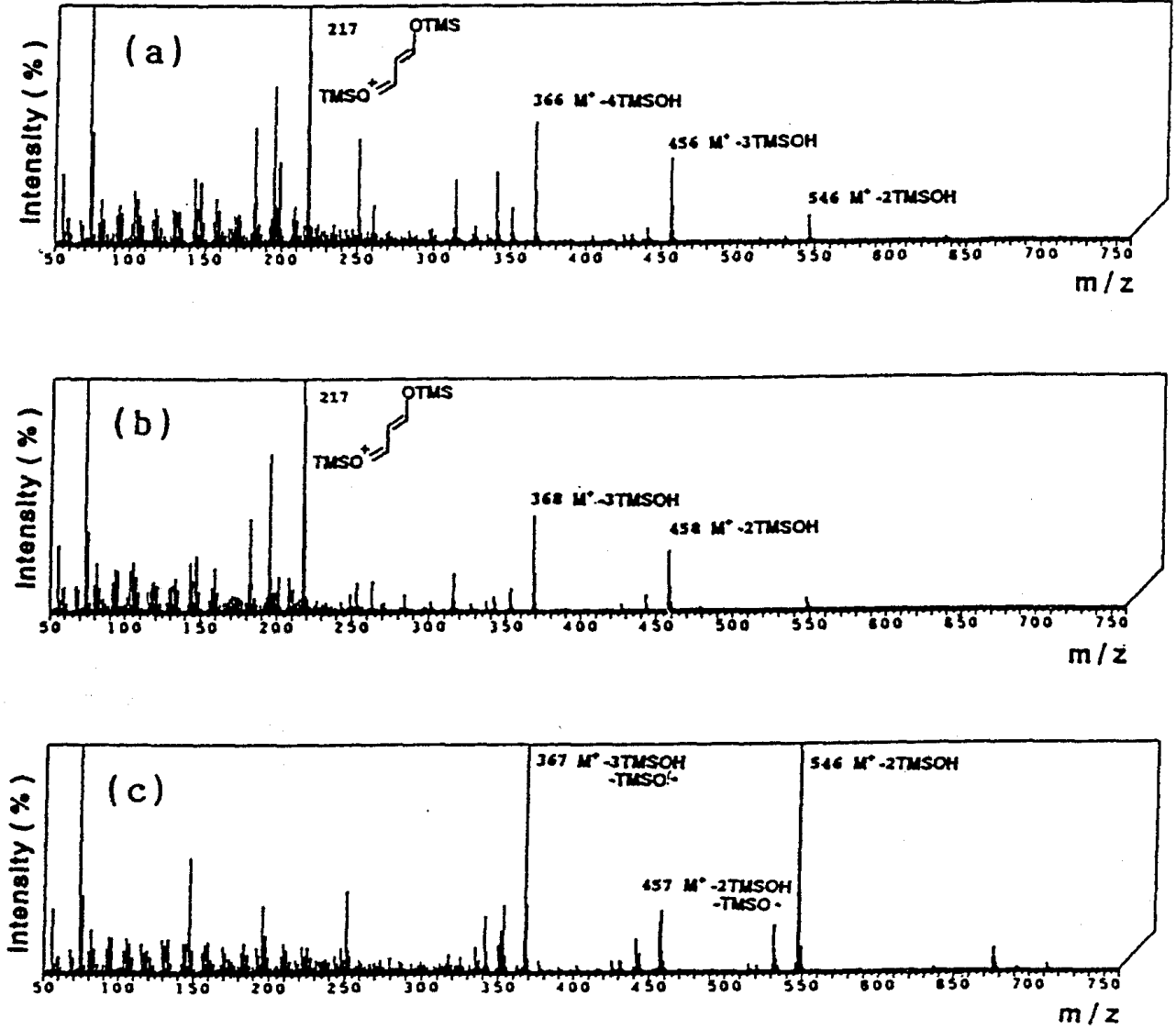

Fig. 4. Mass Spectra of the Me-TMS Derivatives of CA- $1 \beta$-ol (a) and CDCA- $1 \beta$-ol (b) and CA- $6 \alpha$-ol (c) 


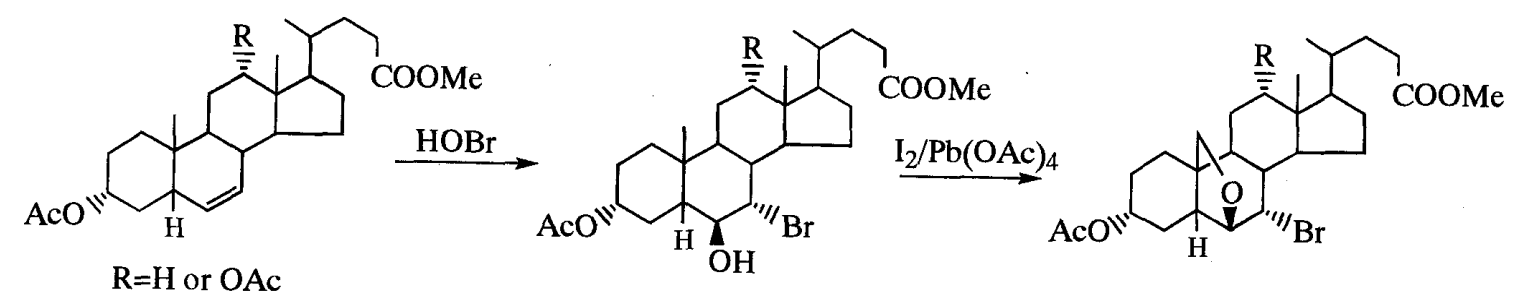

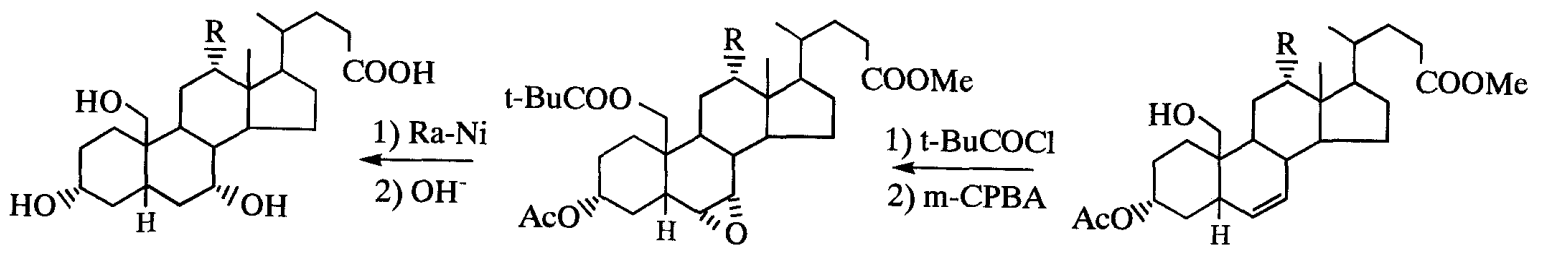

CA-19-ol : $\mathrm{R}=\mathrm{OH}$

CDCA-19-o1 : R=H

Fig. 5. Synthesis of 19-Hydroxylated Bile Acids

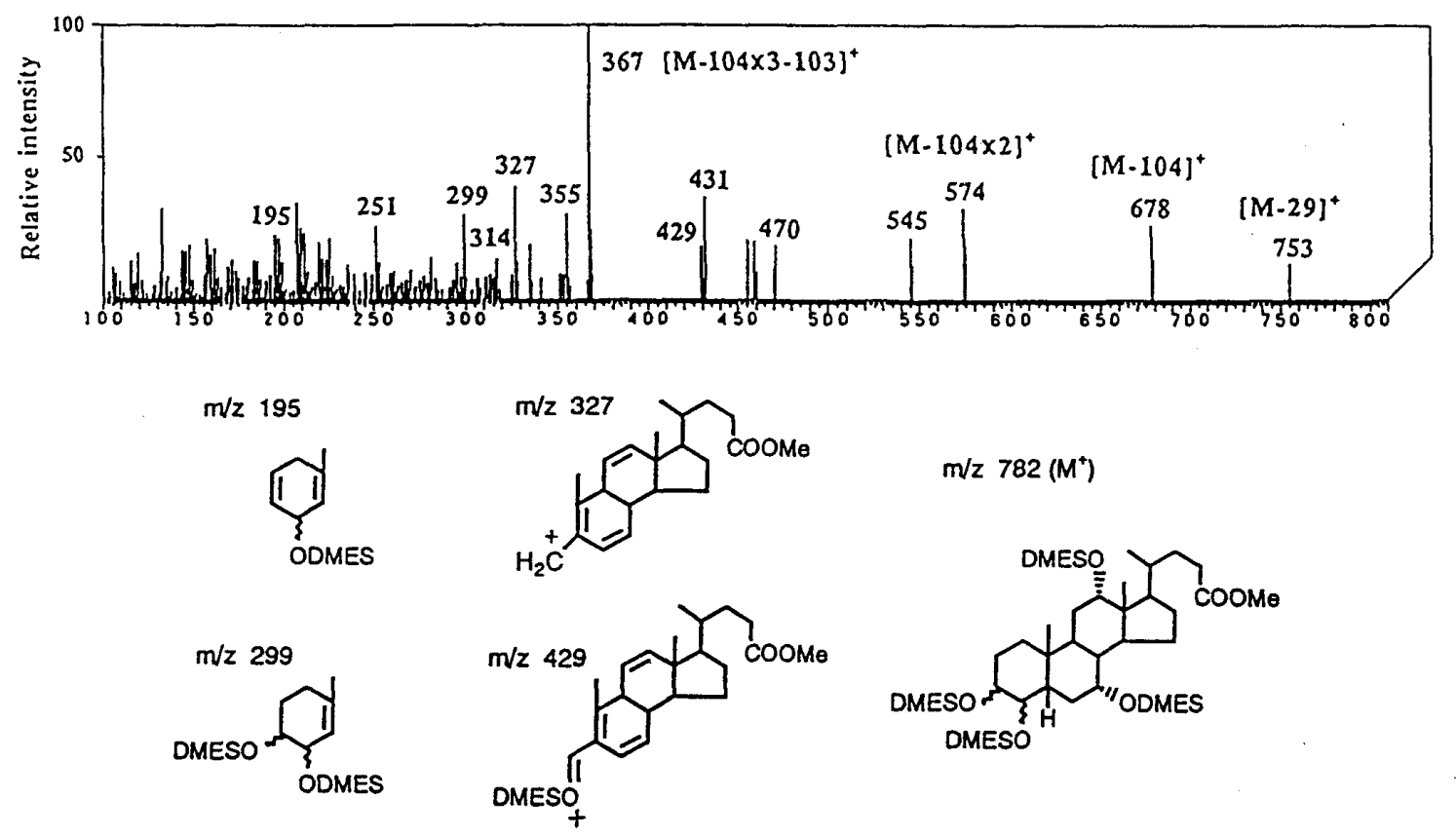

Fig. 6. Mass Spectrum of the Me-DMES Derivative of $3 \beta, 4 \beta, 7 \alpha, 12 \alpha$-Tetrahydroxy-5 $\beta$-cholanoic Acid

マススペクトル (Fig. 4) と保持時間 (Table 1) が共に新生児体液中の成分とそれぞれ一致する ことより，これまで不明であった水酸基の立体配置を含めて上記胆汁酸の化学構造を確認し, 同定することができた。ささらに生体液中には構造未知の胆汁酸の存在が認められたので, GC-MSにより精查し，それぞれを化学合成して得た標品と比較したところ，上記胎児性胆汁

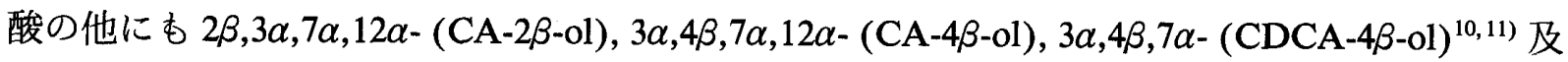
び $3 \alpha, 7 \alpha, 12 \alpha, 19$-水酸化胆汁酸 (CA-19-ol, Fig. 5) ${ }^{12}$ ) が見出され, さらに $3 \beta, 4 \beta, 7 \alpha, 12 \alpha$-水酸化胆 汁酸 $\left(3 \beta, 4 \beta, 7 \alpha, 12 \alpha\right.$-ol, Fig. 6) ${ }^{13)}$ 等の生成経路の理解が困難なものを含めて 14 種に及 3 胎览性 
Table 1. Gas Chromatography-Mass Spectrometric Analysis of the Methyl Ester-Trimethylsilyl Ether Derivatives of Bile Acids

\begin{tabular}{|c|c|c|c|c|c|c|}
\hline \multirow{3}{*}{$\frac{\text { Bile acid }}{5 \beta-\text { Cholanoic acid }}$} & \multicolumn{2}{|c|}{ Rel. retention times } & \multirow{3}{*}{$\underbrace{\text { Base peak }}_{217^{c}}$} & \multirow{2}{*}{\multicolumn{3}{|c|}{$\begin{array}{l}\text { Fragment ions, } m / z \\
\text { (Rel. intensity, \%) }\end{array}$}} \\
\hline & \multirow{2}{*}{$\frac{\text { Poly I-110 }}{1.00^{a)}}$} & \multirow{2}{*}{$\frac{\mathrm{SE}-30}{1.00^{b)}}$} & & & & \\
\hline & & & & 257 (24), & 359 (17), & $374(15)$ \\
\hline $\mathrm{CA}-1 \beta-\mathrm{ol}$ & 0.71 & 2.88 & $217^{c)}$ & 251 (11), & 366 (18), & $456(17)$ \\
\hline CDCA- $1 \beta-o l$ & 1.18 & 3.22 & $217^{c)}$ & 368 (16), & 458 (9), & $548 \quad(3)$ \\
\hline DCA- $1 \beta$-ol & 0.94 & 2.70 & $217^{c)}$ & $253(6)$ & $343 \quad(5)$ & 548 (12) \\
\hline LCA- $1 \beta$-ol & 1.60 & 2.69 & $217^{c)}$ & 147 (5), & $370 \quad(3)$ & $460(10)$ \\
\hline $\mathrm{HCA}$ & 1.00 & 2.79 & 458 & 147 (28), & 159 (15), & $369^{c)}(43)$ \\
\hline$\Delta^{5}-3 \beta-\mathrm{ol}$ & 1.96 & 2.14 & 129 & 249 (17), & $370^{c)}(35)$ & $460(13)$ \\
\hline$\Delta^{5}-3 \beta, 7 \alpha$-diol & 1.15 & 2.35 & $458^{c)}$ & 159 (7), & 208 (6), & $548 \quad(3)$ \\
\hline$\Delta^{5}-3 \beta, 12 \alpha$-diol & 1.31 & 2.63 & $253^{c)}$ & 368 (23), & 458 (13), & $533 \quad(2)$ \\
\hline$\Delta^{4}-3-\mathrm{oxo}-7 \alpha-\mathrm{ol}$ & 2.35 & 2.88 & $384^{c)}$ & 369 (12), & 459 (30), & $474(10)$ \\
\hline $\mathrm{CA}$ & 0.84 & 2.48 & $253^{c)}$ & 343 (28), & $368(51)$ & $458(26)$ \\
\hline $\mathrm{CDCA}$ & 1.21 & 2.41 & $\left.370^{c}\right)$ & $255(25)$, & 353 (23), & $460 \quad(3)$ \\
\hline DCA & 1.08 & 2.36 & $255^{c)}$ & 370 (16), & 460 (2), & $535 \quad(6)$ \\
\hline LCA & 1.54 & 1.90 & 215 & 357 (24), & $372^{c)}(80)$ & 462 (1) \\
\hline Cholesterol & 1.23 & 2.07 & 129 & 329 (91), & $368^{c)}(62)$ & $458(28)$ \\
\hline
\end{tabular}

a) $10.0 \mathrm{~min}$ at $250^{\circ} \mathrm{C}$. b) $7.4 \mathrm{~min}$ at $250^{\circ} \mathrm{C}$. c) Fragment ions used for selected ion monitoring.

胆汁酸の存在を明らかにすることができた。

2）胎児性胆汁酸のガスクロマトグラフィー質量分析法による微量定量一一胎児性胆汁酸の 化学量論的研究を進めることを目的として，これらの微量定量分析法の開発について検討し た，生体試料中の胆汁酸は，水酸基数や抱合型の差異により分配係数が大きく異なるので，従 来の溶媒抽出法では体液中の胆汁酸成分のすべてを定量的に捕捉することは極めて困難であ る.そこで, 各種体液の前処理法として逆層系オクタデシルシラン結合型シリカ Bond Elut C18 を用いる固相抽出法を各種の胆汁酸並びにその抱合型に適用して分析条件を検討した。抱 合型胆汁酸は $2 \mathrm{M}$ 塩酸・エタノールーアセトン (1:9) 中で加熱してソルボリシスを行ったのち, $4 \mathrm{M}$ 水酸化ナトリウムーメタノール $(1: 1)$ 中で加熱して加水分解し, 生成した遊離型胆汁酸を Piperidinohydroxypropyl Sephadex LH-20 (PHP-LH-20) ${ }^{14)}$ カラムを用いて精製し，メチルエス テル・ジメチルエチルシリルエーテル誘導体とする前処理法を確立した (Fig. 7).

これらの誘導体を電子衝撃イオン化 (EI) による GC-MS の特性イオンを用いてセレクトイ オンモニターリング (SIM) を行い，胎児性胆汁酸及び胆汁酸常成分の一斉微量分析法を開発 して, 各胆汁酸の $1 \mathrm{ng}$ を定量することが可能になった (Fig. 8). ${ }^{15-19)}$ しかし, 本法では少なく とも血清の $0.2-0.5 \mathrm{ml}$ を必要とするが, 新生児の血液は, 成人の場合と異なりみだりに採取す ることが許されないので，分析試料の入手は極めて困難である。したがって，これまで新生児 の血液を用いる胆汁酸の研究はほとんど進展しなかった。

血液試料として比較的入手の容易な新生児の出生後 5 日検診時に採取される浸染血液乾燥濾 紙の利用を考えると，さらに分析法の高感度化を図る必要がある。そこで胆汁酸をペンタフル オロベンジルエステル・ジメチルエチルシリルエーテル誘導体とし，反応ガスにイソブタンを 用いる化学イオン化 $(\mathrm{CI})$ により生成した負イオンを検出する GC-MS から，Fig. 9 に示すマス スペクトルを得た。分析条件を検討の結果, 血清 1-5 $\mu 1$ (1 滴以下) 又は Guthrie 法により採取 した浸染血液乾燥濾紙 $1 \mathrm{disc}$ (直径 $3 \mathrm{~mm}$, 約 $2.5 \mu \mathrm{l}$ の血液を含む) 中の胆汁酸を超音波を用い 
Biological Fluids (Urine $0.5 \mathrm{ml}$, Meconium $1 \mathrm{mg}$ )

I.S. $3 \alpha, 6 \beta, 7 \beta, 12 \alpha$-Tetrahydroxy-5 5 -cholan-24-oic acid

Bond Elut C18

washed with $\mathrm{H}_{2} \mathrm{O} 5 \mathrm{ml}$, eluted with $\mathrm{CHCl}_{3} / \mathrm{MeOH}$ (9:1) $4 \mathrm{ml}$

Solvolysis

at $\mathrm{pH} 1$ with $2 \mathrm{M} \mathrm{HCl}$ in $\mathrm{EtOH} /$ acetone $(1: 9) 2 \mathrm{ml}, 38^{\circ} \mathrm{C}, 1 \mathrm{hr}$

Hydrolysis

in $4 \mathrm{M} \mathrm{NaOH} / \mathrm{MeOH}(1: 1) 2 \mathrm{ml}, 80^{\circ} \mathrm{C}, 16 \mathrm{hr}$ then acidified to $\mathrm{pH} 1$

Bond Elut C18

washed with $\mathrm{H}_{2} \mathrm{O} 5 \mathrm{ml}$, eluted with $90 \% \mathrm{EtOH} 5 \mathrm{ml}$

Piperidinohydroxypropylsephadex LH-20

washed with $90 \% \mathrm{EtOH} 2 \mathrm{ml}$, eluted with $0.1 \mathrm{M} \mathrm{AcOH}$ in $90 \% \mathrm{EtOH} 5 \mathrm{ml}$

Derivatization

Diazomethane/ether, Dimethylethylsilylimidazole

Gas Chromatography/Mass Spectrometry (SIM)

Fig. 7. Procedure for GC-MS Analysis of Bile Acids in Biological Fluids

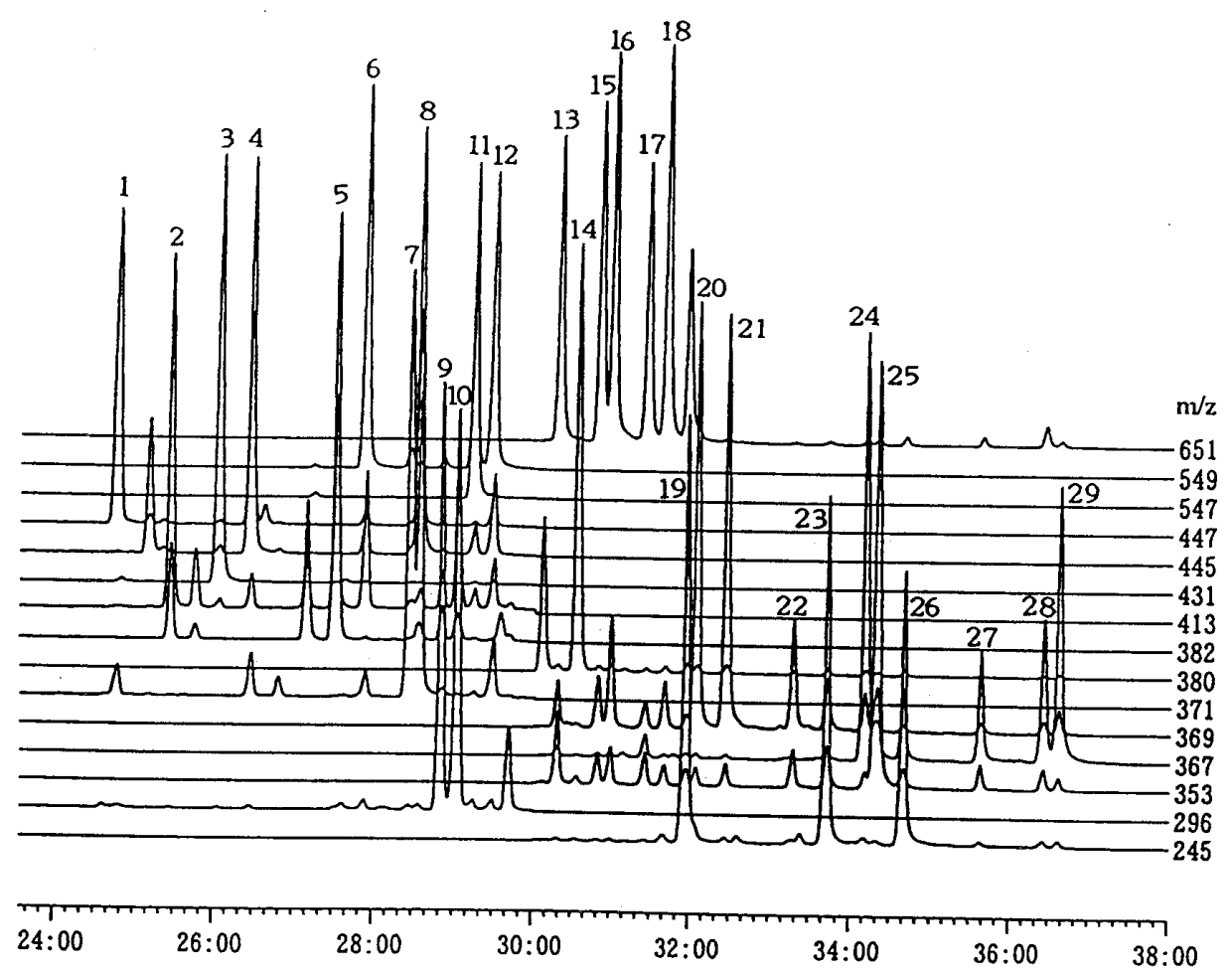

Fig. 8. Selected Ion Monitoring of the Me-DMES Derivatives of Bile Acids

Peaks 1: LCA, 2: CDCA- $\Delta^{4,6}$-3-one, 3: norCDCA (I.S.), 4: $\Delta^{5}-3 \beta$-ol, 5: CDCA- $\Delta^{4}-3-$ one, 6: DCA, 7: allo-CDCA, 8: CDCA, 9: CA- $\Delta^{1}-3$-one, 10: CA- $\Delta^{4,6}$-3-one, 11: $\Delta^{5}$ 3 $\beta, 12 \alpha$-diol, 12: UDCA, 13: CA-3 $\beta$-ol, 14: CA- $\Delta^{4}-3$-one, 15: allo-CA, 16: CA, 17: UCA, 18: DCA-6 $\alpha$-ol, 19: DCA-1 $\beta$-ol, 20: HCA, 21: CDCA-2 $\beta$-ol, 22: CDCA-4 $\beta$-ol, 23: CDCA-

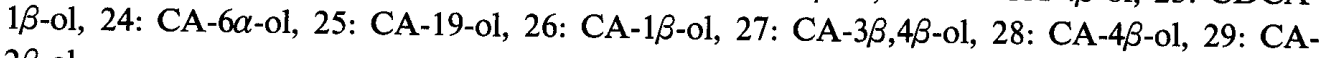
$2 \beta$-ol. 

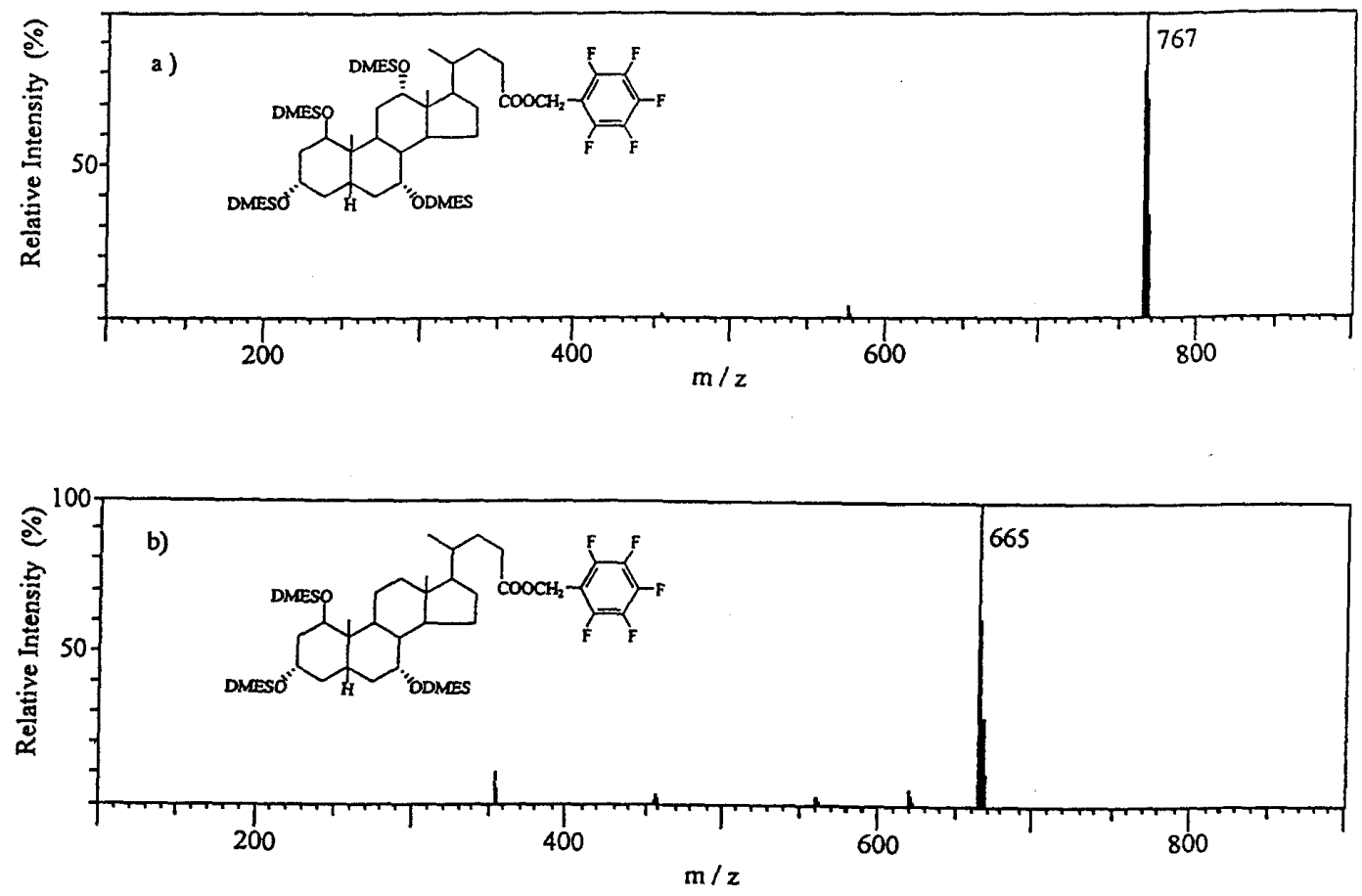

Fig. 9. Negative Ion-Chemical Ionization Mass Spectra of the PFB-DMES Derivatives of CA-1 $\beta$-ol (a) and CDCA-1 $\beta$-ol (b)

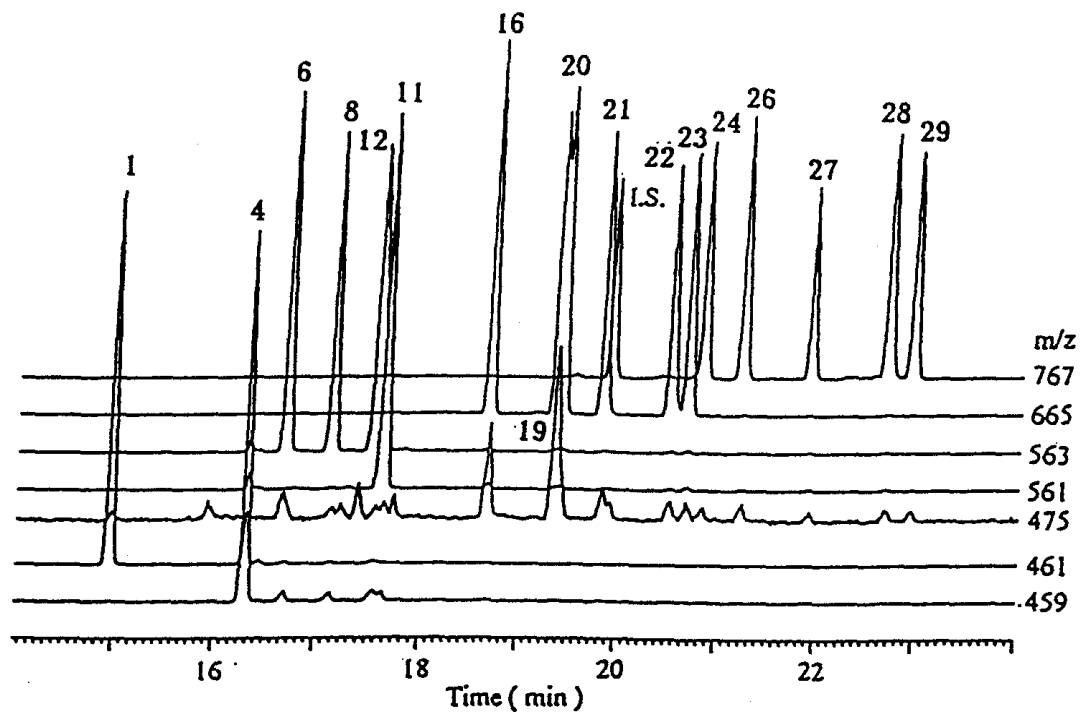

Fig. 10. Selected Negative Ion Monitoring of the PFB-DMES Derivatives of Bile Acids

For abbreviation of peaks, see Fig. 8. I.S.: $3 \alpha, 6 \beta, 7 \beta, 12 \alpha$-tetrahydroxy-5 $\beta$-cholanoic acid.

てメタノールで抽出したのち, 上記誘導体として負イオン検出 SIM 法 (Fig. 10) により高感度 化を達成した．本法により測定範囲 $0.1-100 \mathrm{pg}$ の超微量一斉分析が可能になり（検出限界 1 $\mathrm{fg}$ ), 先の EI 法に比して約 10000 倍の感度を得て, 早期産児や新生児の血液中胎児性胆汁酸の 体内動態に関する研究を展開することができた. ${ }^{20-23)}$

3）抱合型胎児性胆汁酸の高速液体クロマトグラフ法による定量一生体液中の胆汁酸は, それぞれグリシン, タウリン抱合型及びサルフェートとして存在するので, 各成分の抱合型式 


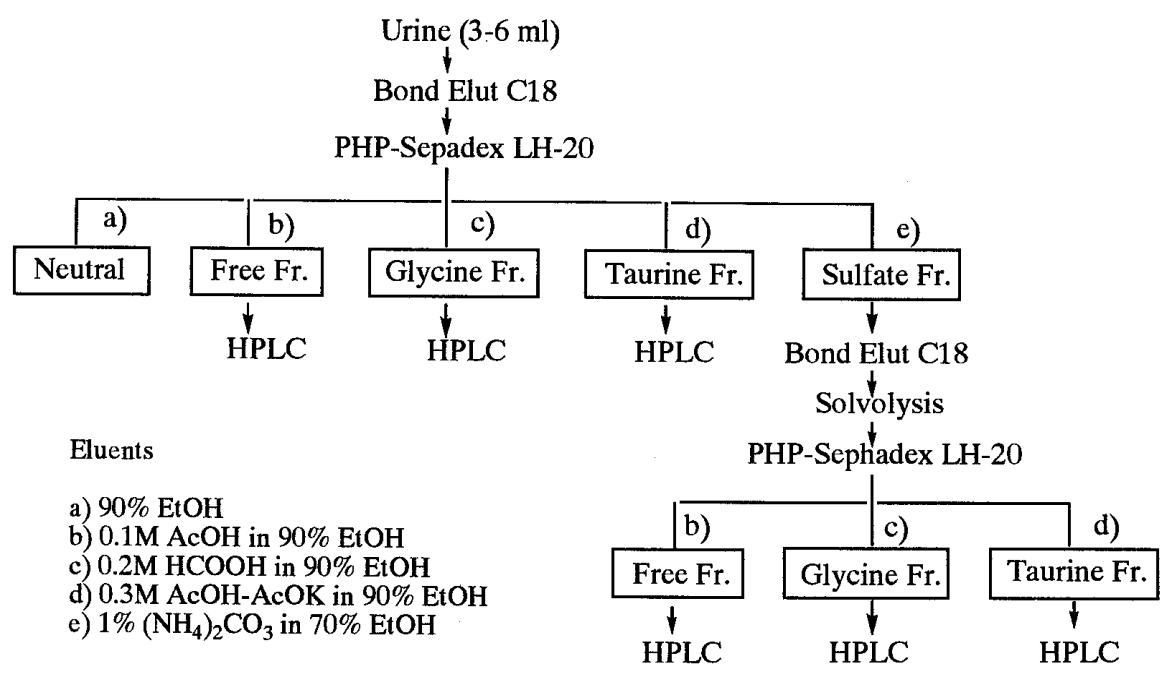

Fig. 11. Procedure for HPLC Analysis of Conjugated Bile Acids

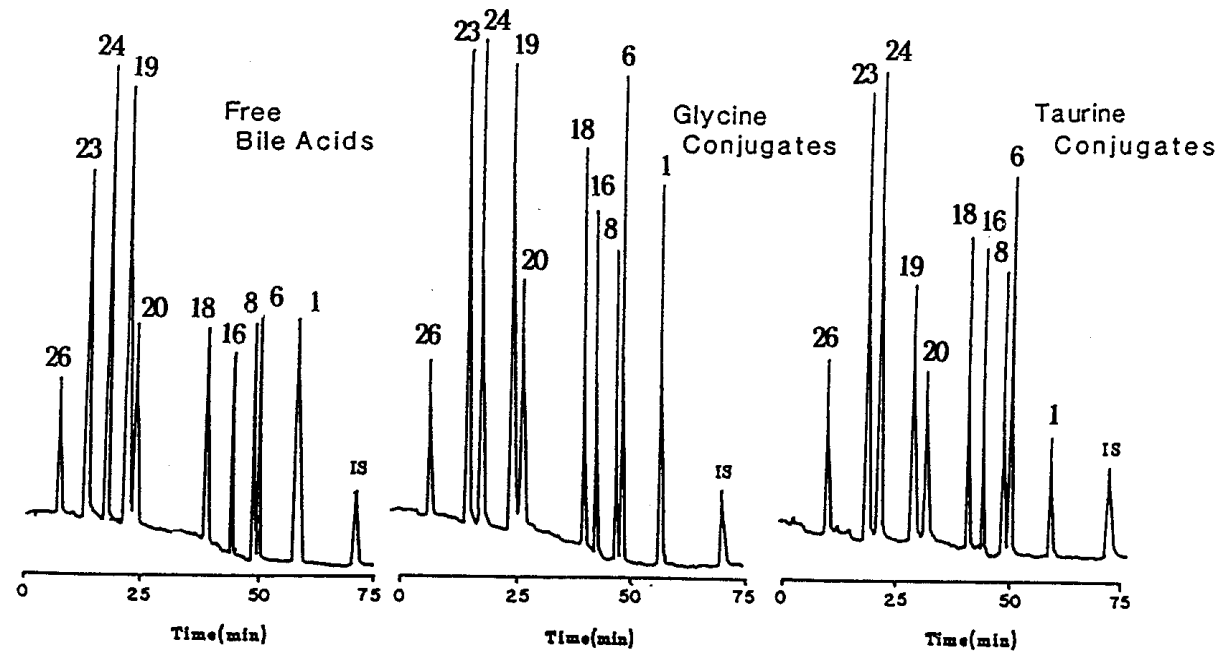

Fig. 12. HPLC of Conjugated Bile Acids

For number and abbreviation of bile acids in conjugates, see Fig. 8.

を保持したまま GC-MS で分析することは極めて困難である．通常，抱合型胆汁酸の測定は， ソルボリシスを行って $3 \alpha$-水酸基を遊離型としたのち， $3 \alpha$-hydroxysteroid dehydrogenase の固定 化酵素カラムで生成した NADH を蛍光検出する HPLC 法が広く用いられている.この方法で は胎児性胆汁酸に対する感度は低く, CA-1 $\beta-01$ の感度は CA の 1/100 以下と低值を示すので, これまで新生児体液中の胎児性胆汁酸は検出されることなく，成人における胆汁酸常成分のみ が分析されてきた。

高感度微量定量法の開発を目的として，辻らにより開発されたルシゲニンを用いる化学発光 検出法を適用して高感度化を試み，さらにPHP-LH-20による抱合型胆汁酸の分画とソルボリ シスの組合せにより Fig. 11 に示す分画法を確立して，アミノ酸抱合とサルフェートの二重抱 合型胆汁酸の高感度系統分析法を開発し，抱合型胆汁酸の 4-100 ng を分析することが可能に なった (Fig. 12). ${ }^{24)}$ しかし， $3 \alpha$-hydroxysteroid dehydrogenase の各胆汁酸に対する酵素活性は Table 2 に示すように，それぞれに対して大きな差異が認められた. ${ }^{24,25)}$ そこで, 本酵素反応に 
Table 2. Kinetic Parameters of $3 \alpha$-Hydroxysteroid Dehydrogenase for Bile Acids

\begin{tabular}{|c|c|c|c|c|c|c|}
\hline \multirow{2}{*}{ Bile acid } & \multicolumn{2}{|c|}{ Free } & \multicolumn{2}{|c|}{ Glycine } & \multicolumn{2}{|c|}{ Taurine } \\
\hline & $K_{\mathrm{m}}$ & $V_{\max }$ & $K_{\mathrm{m}}$ & $V_{\max }$ & $K_{\mathrm{m}}$ & $V_{\max }$ \\
\hline CA- $1 \beta-\mathrm{ol}$ & 151.5 & 2.5 & 33.3 & 0.43 & 133.3 & 8.3 \\
\hline CDCA- $1 \beta$-ol & 109.9 & 3.0 & 80.0 & 0.67 & 14.3 & 5.6 \\
\hline DCA- $1 \beta$-ol & 16.0 & 2.0 & 41.7 & 7.4 & 6.8 & 3.3 \\
\hline CA- $6 \alpha-o l$ & 20.0 & 3.8 & - & - & - & - \\
\hline HCA & 9.8 & 2.0 & 4.6 & 5.9 & 20.0 & 8.3 \\
\hline $\mathrm{CA}$ & 13.2 & 9.1 & 5.9 & 7.7 & 18.9 & 5.5 \\
\hline CDCA & 8.3 & 15.4 & 1.9 & 6.3 & 3.2 & 5.9 \\
\hline DCA & 2.5 & 3.5 & 1.8 & 2.7 & 7.8 & 2.6 \\
\hline LCA & 1.4 & 2.5 & 2.9 & 3.6 & 12.1 & 1.4 \\
\hline
\end{tabular}

Values for $K_{\mathrm{m}}(\mu \mathrm{M})$ and $V_{\max }(\mu \mathrm{mol} / \mathrm{min} / \mathrm{mg})$ were determined for the negative intercept and slope from the least square regression line at each substrate concentration in the Lineweaver-Burk plots.

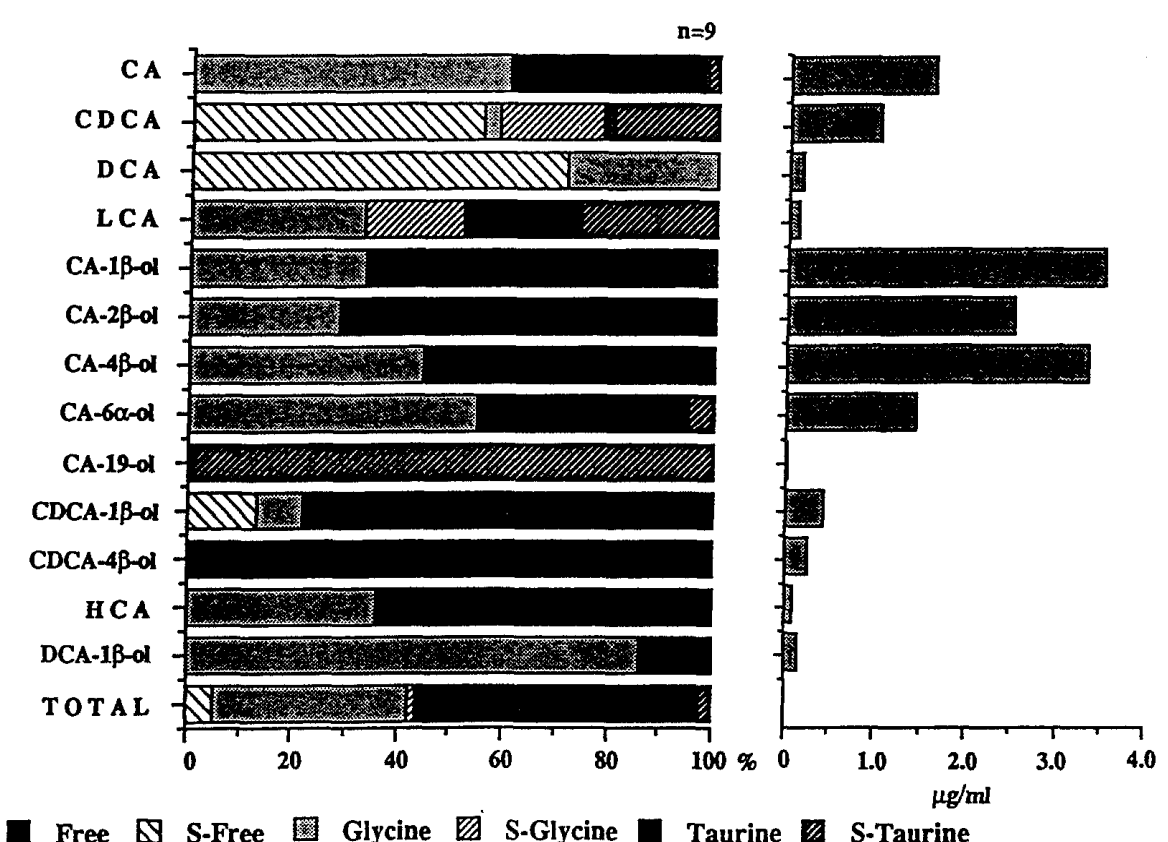

Free $\$$ S-Free Glycine S-Glycine

Taurine S-Taurine

Fig. 13. Profile and Composition of Conjugated Bile Acids in Neonatal Urine

よらずに胆汁酸の 3-位水酸基を1-アンスロイルニトリル26)でプレラベル化したのち，蛍光検出

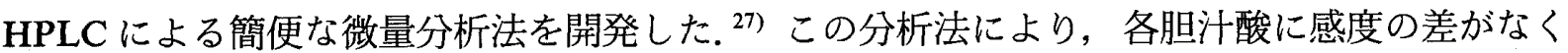
$500 \mathrm{pg}$ まで分析が可能になり，従来法ではその存在が見過されていた微量の抱合型胎児性胆汁 酸に関する研究を展開することができた。

この蛍光検出 HPLCによる微量定量法を用いて，胎便及び新生児尿中の抱合型胎児性胆汁 酸について検討したところ，各胆汁酸はその化学構造により抱合型組成比に大きな差異が認め られた (Fig. 13). 従来の胆汁酸常成分は主としてタウリン又はサルフェートの抱合型として存 在するが，水酸基数の多い胎児性胆汁酸の場合はサルフェート抱合されることなくタウリン抱 合型として排泄されている．したがって，新生児尿中のサルフェート抱合型は総胆汁酸量の約 $9 \%$ にとどまり，成人尿の場合にグリシン・サルフェートの二重抱合型が $85 \%$ 以上に及ぶのと は大きく異なることが判明した。 さらに妊婦尿における抱合型胆汁酸の組成は Fig. 14 に示す 


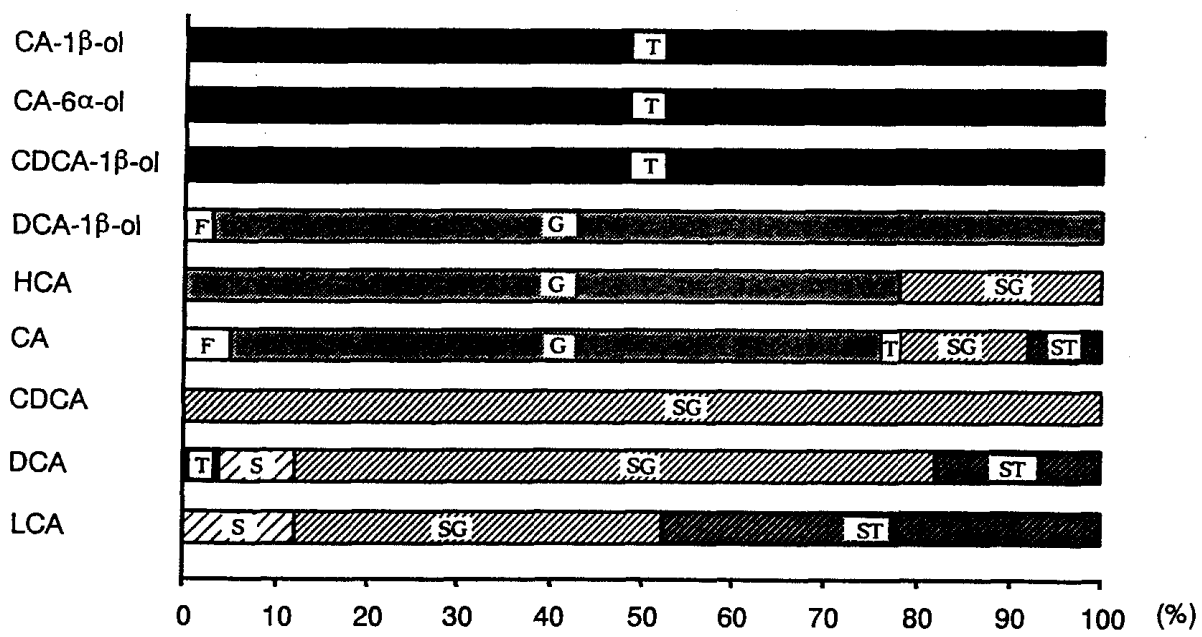

Fig. 14. Composition of Conjugated Bile Acids in Urine from Pregnant Women

F, unconjugate; G, glycine; T, taurine; S, sulfate; SG, glycine-sulfate; ST, taurinesulfate.

ように，成人における常成分の CA, CDCA, DCA がグリシン抱合型として排泄されるのに対 し, CA-1 $\beta$-ol, CDCA-1 $\beta$-ol は夕ウリン抱合型であり, 抱合形式が明らかに異なることが認めら れた. この結果，これらの $1 \beta$-水酸化胆汁酸は胎児に由来して胎盤経由により妊婦尿中に排泄 されたものと考えられ, 妊婦尿の検査により胎児の発育状態を知ることが出来るあのと期待さ れている.

1-2. 胎児-新生児期における胆汁酸の体内動愁 1) 胎児-新生児体液中の胎児性胆汁 酸一一胎便から胎児性胆汁酸が多量に検出されたので, これらの体内動態及び生成機序の解明 を目的として, 胎便, 羊水及び新生児尿の分析を行い, 胎児一新生児期体液中の胆汁酸組成につ いて検討した．その結果を Table 3 に示す. ${ }^{28)}$ 胎便中には，多量の $1 \beta$-及び $6 \alpha$-水酸化胆汁酸が 存在し, CDCA の $6 \alpha$-水酸化体であるヒョコール酸 $(\mathrm{HCA})$ が主成分（総胆汁酸量の 29\%）を なすのに対し，羊水及び新生児尿では CA の $1 \beta$-位が水酸化された CA- $1 \beta-\mathrm{ol}$ が主成分（それぞ れ 40,45\%) であることが判明した。

次いで, 新生児血液中の胆汁酸組成を明らかにするため, 出生後 5 日検診時に採取した浸染 血液乾燥濾紙から胆汁酸を抽出して分析したところ, 血液中の胆汁酸組成は胎便や新生児尿の 場合とは異なり，CA 及び CDCA が主成分として存在し，健常成人の場合に近いことが明らか になった (Table 4). ${ }^{29,30)}$

胆汁酸の本来の生理的意義を考えるとき, 胆汁酸の $1 \beta$-及び $6 \alpha$-水酸化は胎生期における胆 汁酸の排泄機構の 1 つと考えられる。そこで, 各体液中の胆汁酸組成を比較して体内動態を 検討することを目的に，尿又は胎便中の総胆汁酸量に対する各胆汁酸の組成比 $(\mathrm{U}, \mathrm{M}, \%)$ と血 液中胆汁酸 (B) の場合との相対比（U/B 又は M/B）を求め, Table 4 に示した. この相対比が 1.00 以下の場合, 胆汁酸は血液中に多く存在し, 腸肝循環型胆汁酸として体内にとどまる。一 方, 1.00 以上の場合はその体液中に多く排泄される排泄型胆汁酸と考えられる。この結果, CDCA は主に $6 \alpha$-位が水酸化されて便中に排泄され, CA は $1 \beta$-位が水酸化されて尿中に排泄さ れるので，血液中には成人の場合之同様に胆汁酸常成分の CA と CDCA が主成分として存在 し, 生体の恒常性を維持しているあのと推論される。 ${ }^{22,23)}$ また, 胎便と尿, 羊水における胆汁酸 
Table 3. Bile Acids in Biological Fluids from Fetus-Neonate and Adult

\begin{tabular}{|c|c|c|c|c|c|}
\hline \multirow[b]{2}{*}{ Bile acid } & \multicolumn{3}{|c|}{ Fetus-Neonate } & \multicolumn{2}{|c|}{ Adult } \\
\hline & $\begin{array}{l}\text { Meconium } \\
\mu \mathrm{g} / \mathrm{mg}(\%)\end{array}$ & $\begin{array}{l}\text { Amniotic fluid } \\
\mu \mathrm{g} / \mathrm{ml}(\%)\end{array}$ & $\begin{array}{c}\text { Urine } \\
\mu \mathrm{g} / \mathrm{ml}(\%)\end{array}$ & $\begin{array}{c}\text { Urine } \\
\mu \mathrm{g} / \mathrm{ml}(\%)\end{array}$ & $\begin{array}{c}\text { Fece } \\
\mu \mathrm{g} / \mathrm{mg}(\%)\end{array}$ \\
\hline CA & $0.70(27.0)$ & $0.28(28.4)$ & $0.34(15.2)$ & $0.31(26.7)$ & $3.69(39.1)$ \\
\hline CDCA & $0.42(16.3)$ & $0.19(18.9)$ & $0.27(11.8)$ & $0.30(25.9)$ & $1.77(18.8)$ \\
\hline DCA & $0.06 \quad(2.4)$ & $0.01 \quad(1.0)$ & $0.01 \quad(0.6)$ & $0.30(25.9)$ & $3.81(40.4)$ \\
\hline LCA & $0.16 \quad(6.0)$ & $0.05 \quad(5.0)$ & tr. & $0.17(14.7)$ & $0.17(1.8)$ \\
\hline$A^{5}-3 \beta-\mathrm{ol}$ & $0.06 \quad(2.4)$ & $0.02 \quad(2.0)$ & $0.13 \quad(5.8)$ & $0.01 \quad(0.9)$ & n.d. \\
\hline$\Delta^{5}-3 \beta, 12 \alpha-\mathrm{ol}$ & $0.02 \quad(0.6)$ & $0.02 \quad(2.0)$ & $0.11 \quad(4.9)$ & n.d. & n.d. \\
\hline CA-1 $\beta$-ol & $0.16 \quad(6.3)$ & $0.40(40.0)$ & $1.00(44.5)$ & n.d. & n.d. \\
\hline CDCA- $1 \beta-o l$ & $0.17 \quad(6.7)$ & $0.02 \quad(2.0)$ & $0.27(12.1)$ & n.d. & n.d. \\
\hline DCA-1 $\beta$-ol & $0.04 \quad(2.2)$ & tr. & n.d. & $0.07 \quad(6.0)$ & n.d. \\
\hline LCA- $1 \beta$-ol & n.d. & n.d. & n.d. & n.d. & n.d. \\
\hline CA- $6 a-o l$ & $0.03 \quad(1.2)$ & n.d. & tr. & - & - \\
\hline CDCA- $6 \alpha-o l$ (HCA) & $0.75(29.0)$ & $0.01 \quad(1.0)$ & $0.12 \quad(5.2)$ & - & - \\
\hline CDCA- $6 \beta-o l$ & n.d. & n.d. & n.d. & - & 一 \\
\hline Total $\pm S . D$. & $2.59 \pm 1.36$ & $1.00 \pm 0.76$ & $2.25 \pm 0.78$ & $1.16 \pm 0.52$ & $9.44 \pm 5.74$ \\
\hline
\end{tabular}

Table 4. Differential Compositions of the Bile Acids in Biological Fluids from Normal Neonates

\begin{tabular}{|c|c|c|c|c|c|c|c|c|}
\hline \multirow{2}{*}{ Bile acid } & \multicolumn{2}{|c|}{ Blood $^{a)}(n=17)$} & \multicolumn{2}{|c|}{ Urine $(n=14)$} & \multirow{2}{*}{$\mathrm{U} / \mathbf{B}^{b)}$} & \multicolumn{2}{|c|}{ Meconium $(n=5)$} & \multirow{2}{*}{$\mathbf{M} / \mathbf{B}^{c}$} \\
\hline & $\mu \mathrm{g} / \mathrm{ml}$ & $(\%)$ & $\mu \mathrm{g} / \mathrm{ml}$ & $(\%)$ & & $\mu \mathrm{g} / \mathrm{mg}$ & $(\%)$ & \\
\hline $\mathrm{CA}$ & \multicolumn{2}{|c|}{$2.82 \pm 1.98^{e)}(38.1)$} & \multicolumn{2}{|c|}{$1.22 \pm 1.02^{e)}(10.8)$} & 0.28 & \multicolumn{2}{|c|}{$0.70 \pm 0.50^{e)}(27.0)$} & 0.71 \\
\hline CDCA & $1.36 \pm 0.65$ & $(18.3)$ & $0.15 \pm 0.13$ & (1.3) & 0.07 & $0.42 \pm 0.28$ & $(16.2)$ & 0.89 \\
\hline DCA & $0.10 \pm 0.04$ & (1.4) & n.d. & & & $0.06 \pm 0.02$ & $(2.3)$ & 1.64 \\
\hline LCA & $0.30 \pm 0.32$ & (4.1) & n.d. & & & $0.16 \pm 0.03$ & $(6.2)$ & 1.51 \\
\hline CA-1 $\beta$-ol & $0.31 \pm 0.26$ & $(4.2)$ & $3.45 \pm 2.45$ & $(30.6)$ & 7.29 & $0.16 \pm 0.09$ & $(6.2)$ & 1.48 \\
\hline CA- $2 \beta-$ ol & $0.30 \pm 0.21$ & $(4.1)$ & $2.03 \pm 2.39$ & $(18.0)$ & 4.39 & - & & \\
\hline CA- $4 \beta-$ ol & $0.72 \pm 0.98$ & $(9.7)$ & $0.79 \pm 0.69$ & $(7.0)$ & 0.72 & - & & \\
\hline CA- $6 \alpha-o l$ & $0.15 \pm 0.15$ & $(2.0)$ & $0.79 \pm 0.67$ & $(7.0)$ & 3.50 & $0.03 \pm 0.03$ & $(1.2)$ & 0.60 \\
\hline CDCA-1 $\beta$-ol & $0.14 \pm 0.12$ & $(1.9)$ & $0.32 \pm 0.60$ & $(2.8)$ & 1.47 & $0.17 \pm 0.10$ & $(6.6)$ & 3.47 \\
\hline CDCA- $2 \beta-\mathrm{ol}$ & $0.08 \pm 0.07$ & (1.1) & $0.09 \pm 0.09$ & $(0.8)$ & 0.73 & - & & \\
\hline CDCA- $4 \beta-$ ol & $0.23 \pm 0.17$ & (3.1) & $0.15 \pm 0.20$ & $(1.3)$ & 0.42 & - & & \\
\hline CDCA- $6 \alpha-o l$ (HCA) & $0.06 \pm 0.06$ & $(0.8)$ & $0.77 \pm 1.09$ & $(6.8)$ & 8.50 & $0.75 \pm 0.62$ & $(29.0)$ & 36.3 \\
\hline DCA- $1 \beta$-ol & $0.11 \pm 0.13$ & $(1.5)$ & $0.01 \pm 0.01$ & $(0.1)$ & 0.07 & $0.06 \pm 0.04$ & $(2.3)$ & 1.53 \\
\hline UDCA & $0.05 \pm 0.08$ & $(0.7)$ & n.d. & & & - & & \\
\hline $3 \beta, 4 \beta, 7 \alpha, 12 \alpha$-Tetorol & $0.30 \pm 0.29$ & $(4.1)$ & $1.44 \pm 1.55$ & $(12.8)$ & 3.12 & - & & \\
\hline$A^{5}-3 \beta$-ol & $0.31 \pm 0.41$ & $(4.2)$ & $0.01 \pm 0.02$ & $(0.1)$ & 0.02 & $0.06 \pm 0.04$ & $(2.3)$ & 0.55 \\
\hline$\Delta^{5}-3 \beta, 12 \alpha-$ Diol & $0.06 \pm 0.05$ & $(0.8)$ & $0.05 \pm 0.04$ & $(0.4)$ & 0.50 & $0.02 \pm 0.01$ & $(0.8)$ & 1.00 \\
\hline Total $^{d)} \pm$ S.D. & $7.40 \pm 3.12$ & & $11.27 \pm 7.48$ & & & $2.59 \pm 1.66$ & & \\
\hline
\end{tabular}

a) Blood was extracted from dried blood disc. b) Ratio of bile acids (\%) in urine to blood. c) Ratio of bile acids (\%) in meconium to blood. $d$ ) Mean concentration of total bile acids. e) Mean \pm S.D. n.d.: not detected.

組成比の差異は $1 \beta$-及び $6 \alpha$-水酸化酵素の基質特異性と腸管又は腎における胆汁酸の再吸収の 差より生じたものと考えられ，現在，酵素化学的研究が進められている．以上の結果は胎児一新 生児期における胎児性胆汁酸の生理的機能と意義に関する重要な新知見であり，詳細な臨床医 学的検討を早急に行うことが必要となった。 

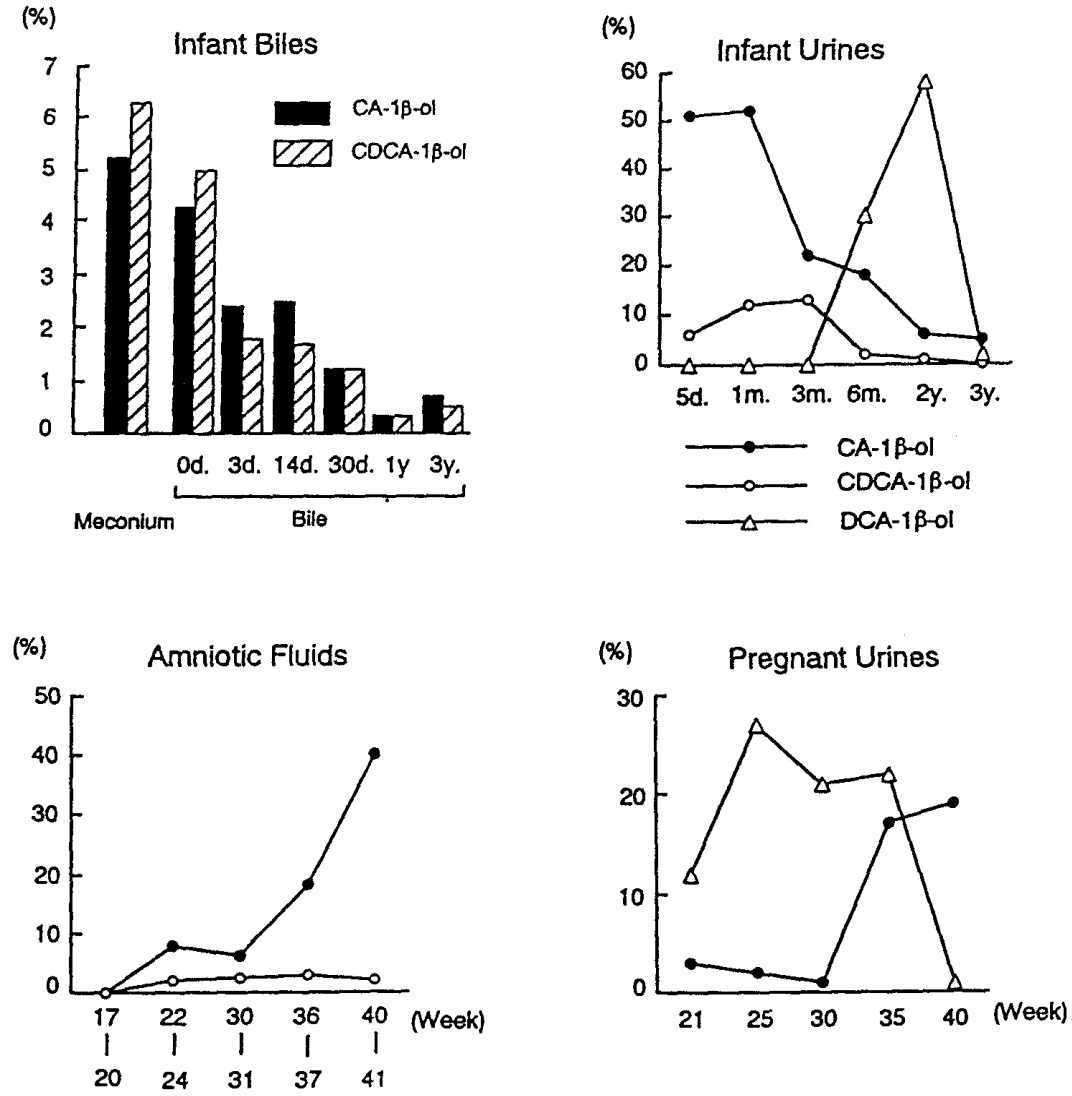

Fig. 15. Developmental Change of $1 \beta$-Hydroxylated Bile Acids in Biological Fluids from Infants and Pregnant Women

2) 成長に伴う胎児性胆汁酸組成の変動——健常成人の体液中には胎児性胆汁酸はほとんど 認められないので, 胎児一新生児の発育に伴う胆汁酸組成の変動について検討することとし た. ${ }^{28)}$ まず，新生児胆汁中の胆汁酸画分について分析したところ，Fig. $15 \mathrm{a}$ に示すように $1 \beta$-水 酸化胆汁酸は，生下時には胎便の場合とほぼ同程度 (5\%) に存在するが，出生後は日齢ととも に低下して 1 才以後は $1 \%$ 以下となり，ほとんど生成しないことが判明した．また，新生児尿 (Fig. 15b) では，CA-1 $\beta-\mathrm{ol}$ は総胆汁酸量の $50 \%$ 以上を占め，ときには $80 \%$ にあ及ぶことを認 めた。これらの胆汁酸は新生児の発育と共に出生後 1 ケ月から減少し，2才までには成人の胆 汁酸組成に近づくことが明らかになった。この際，出生後の腸内細菌叢の発達により二次胆汁 酸の DCA が生成するので，DCA-1 $\beta$-ol は一時的に出現するが， 3 才迄には消失することが認 められた。 これらの結果は，出生後の発育に伴う $1 \beta$-水酸化酵素の活性低下によるすのと考え られる。一方，胎生期における胎児性胆汁酸の体内動態を探ることを目的に羊水及び妊婦尿に ついて検討した。 羊水では Fig. $15 \mathrm{c}$ に示すように，CA-1 $\beta$-ol は妊娠 31 週までは総胆汁酸量の $3 \%$ 以下と低值であるが， 35 週前後からその存在比を増し，妊娠末期の 40 週には最高値 (40\%) を示した。 また，妊婦尿 (Fig. 15d) であ，胎児に由来すると考えられる CA-1 $\beta$-ol は夕ウ リン抱合型として胎盤経由により同時期に排泄されていることが明らかになった。

さらに新生児胆汁中の抱合型胆汁酸についても分析を行い，日齢による抱合型組成の変動に ついて検討した．生下時，出生後 3 日目には，いずれの胆汁酸むタウリン抱合型が主成分であ るが, 出生後 30 日及び 1 年後の胆汁ではタウリン抱合型が減少し，グリシン抱合型が増大する 
ことを認めた。一般に成人胆汁中のグリシン抱合型／タウリン抱合型 $(\mathrm{G} / \mathrm{T})$ の比は通常 3.2 亡 されており，グリシン抱合型が主体となっている．したがって，新生児期の $\mathrm{G} / \mathrm{T}$ 比も $1 \beta$-水酸 化の場合と同様に出生後は徐々に変化して, 成人の組成比に近づくことが明らかになった.

以上，胎児一新生児体液中の胆汁酸組成並びに体内動態は，健常成人の場合と大きく異なり， $1 \beta$-及び $6 \alpha$-水酸化胆汁酸のタウリン抱合型が主要成分をなすが，これらは成長と共に急速に減 少し, 成人の場合の組成に近づくことが明らかになった。 また先述したように妊娠末期の妊婦 尿にも胎児由来のタウリン抱合型 $1 \beta$-水酸化胆汁酸が排泄されるので, 妊婦尿から胎児の発育 状態を知ることの可能性が示された。 胆汁酸が脂質の消化, 吸収に関与する本来の生理学的機 能を考えるとき, 胆汁酸は胎生期には必要がなく, むしろ肝毒性を示す。したがって, 胎児一新 生児尿中に総胆汁酸量の 60-90\% を占める胎児性胆汁酸は, 水酸化により水溶性を増して尿 や便への排泄を促進しているが，出生後は自らの栄養摂取のために胆汁酸が必要になるので, その組成は急速に成人の組成比に近づくあのと考えられる. 胎児性胆汁酸の生理的意義の詳細

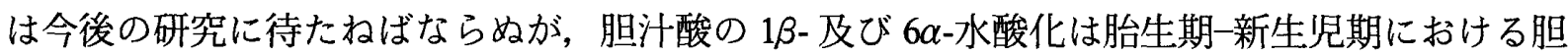
汁酸の重要な排泄機構の 1 つとして新知見を加えることが出来た。これらの結果は新生児肝胆 道疾患の診断及び治療についても大きな波紋を投げ掛け，国内外の臨床小児医学領域において 共同研究が広く展開されているので，その成果が期待される.

3）早期産児医療への応用——胎児性胆汁酸の生成は胎生期の生体防御のための胆汁酸の排 泄機構と考えるとき，早期産児における胆汁酸組成は栄養管理（脂質の消化・吸収）に大きく 影響するすのと考えられる。 そこで, 妊娠 27-38 週出産の早期産児尿中の胆汁酸組成について 検討したところ，それぞれの個体の状態により程度の差異はあるが，いずれの場合も満期出産 之同じく在胎週数から通算して，ほぼ 40 週に達するまでは $1 \beta$-水酸化胆汁酸は増加し，その後

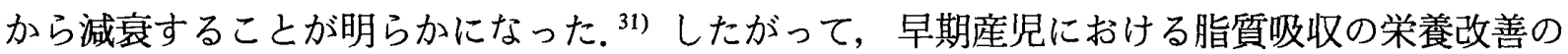
ための胆汁酸補充療法の可能性など早期産児医療への検討が期待される.

1-3. 胎児性胆汁酸の生合成 胎児性胆汁酸の生合成機構については不明な点が多い. Sjövall らは二次胆汁酸の DCA, LCA を胎児肝ホモジネートとインキュベートして, $1 \beta$-水酸化 体の生成を認めている. ${ }^{32}$ 一方，穂下らは胆汁酸生合成の先天代謝異常によるZellweger 症候 群患児尿中から, 胎児性胆汁酸の生合成中間体とも考えられる $1 \beta$-水酸化コレスタン酸 (THCA-1 $\beta-\mathrm{ol})$ を見出しているので, ${ }^{33)}$ 副生成経路の可能性もあり今後に解明すべき課題であ る.

胆汁酸代謝は実験動物により種差が大きく，ヒトにおけるような水酸化はサルにのみ認めら れている. 現在，カニクイザルの肝藏を用いて酵素化学的な研究を進めているが，カニクイザ ルの血液及び肝臓中より $1 \beta-, 2 \beta-, 4 \beta-, 6 \alpha$-水酸化胆汁酸の存在が認められた。また CDCA, DCA，LCA 及びこれらの抱合型について肝ミクロゾームとインキュべートし， $1 \beta-$ 及び $6 \alpha-$ 水 酸化体が生成することを認めた (Fig. 16). 他方, ラット肝ミクロゾームにおいても胆汁酸生合 成中間体である $\mathrm{C}_{27}$ 胆汁酸の THCA, DHCA が $1 \beta$-水酸化されることが判明した。 したがって, 先の穂下らの結果と考え併せるとき胎児性胆汁酸生合成の副経路の存在が示されたことにな る.

なお，胆汁酸生合成における $\beta$-酸化による側鎖切断の立体化学的機構については，未だに不 明確な点が多い，黒澤らは，Fig. 17 に示すように $\beta$-ケトスルホキシドの熱分解を利用して $\alpha \beta$ 不飽和ケトンを合成し，これを鍵化合物として胆汁酸生合成中間体並びに関連する $\mathrm{C}_{27}$ 胆汁酸

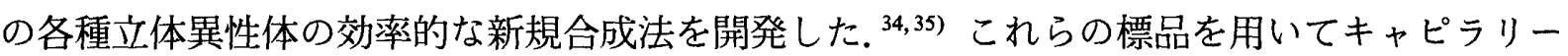



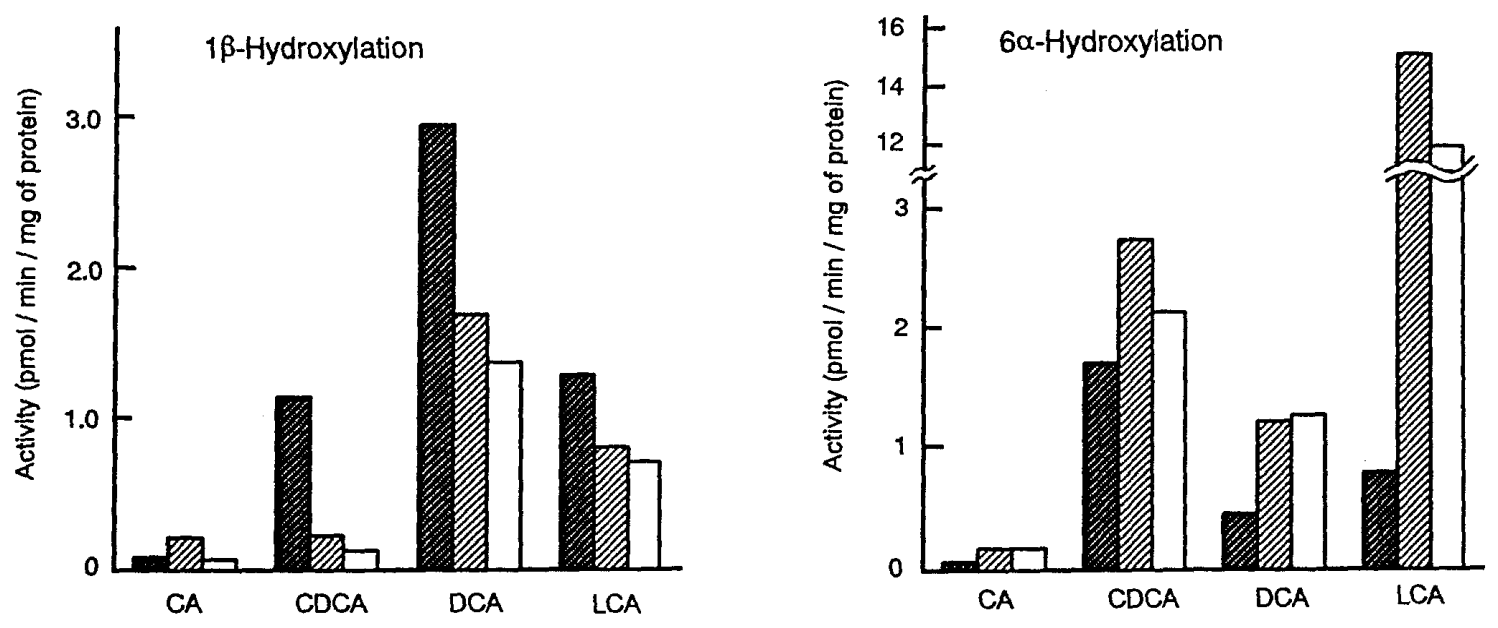

Unconjugate $\mathbb{Z}$ Glycine $\square$ Taurine

Fig. 16. Activities of $1 \beta$ - and $6 \alpha$-Hydroxylase in Monkey Liver Microsomes

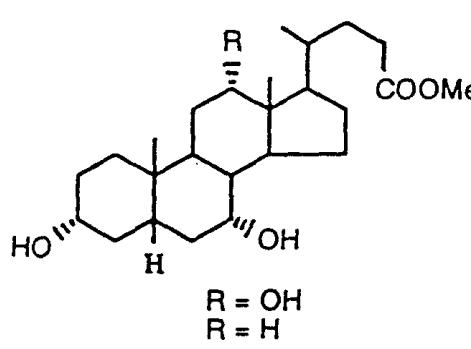<smiles>CC(=O)C(C)(P)C(C)(P)OC1CCC(C)C23CCCC2CC1C3</smiles><smiles>CC(CC(O)CCC(C)C1C2CCCC1CC2)C(=O)O</smiles><smiles>CC(C)CCC(C)C1CCC2CCC21</smiles>

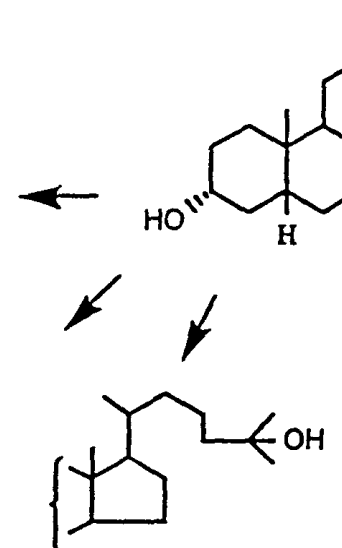<smiles>C1=CC=C1</smiles><smiles>C1CCC1</smiles><smiles>CCC(C)C(CC)C(C)(CC)CCCC(=O)O</smiles><smiles>CC(C)C(O)CCC(C)C1CC2CCC1C2</smiles><smiles>CC(O)CCCC(C)C1CCC2CCC21</smiles><smiles>CC(CCC(O)C(C)(C)O)C1CC2CCC2C1</smiles>

Fig. 17. Synthesis of $\mathrm{C}_{27}$-Bile Acids and Alcohols

GC 及び HPLC による高性能な定量法を開発して, 胆汁酸生合成機構の立体化学的研究を進め ており，その成果を期待したい. ${ }^{36,37)}$

1-4. 胎児性胆汁酸を指標とする新生児肝胆道疾患の病態解析 従来，小児期における胆 汁酸代謝は，成人の場合と同様に考えられたので，小児の肝胆道疾患に対する肝機能検查には 成人における胆汁酸常成分の分析法が利用されてきた。 上述の研究結果から，各種の新生児肝 胆道疾患におおる胎児性胆汁酸の体内動態を解明することは早急に解決すべき課題となった。 著者らは, 数多くの臨床医学研究室の理解を得て, 共同研究が進められているので, その概略 を記す。 


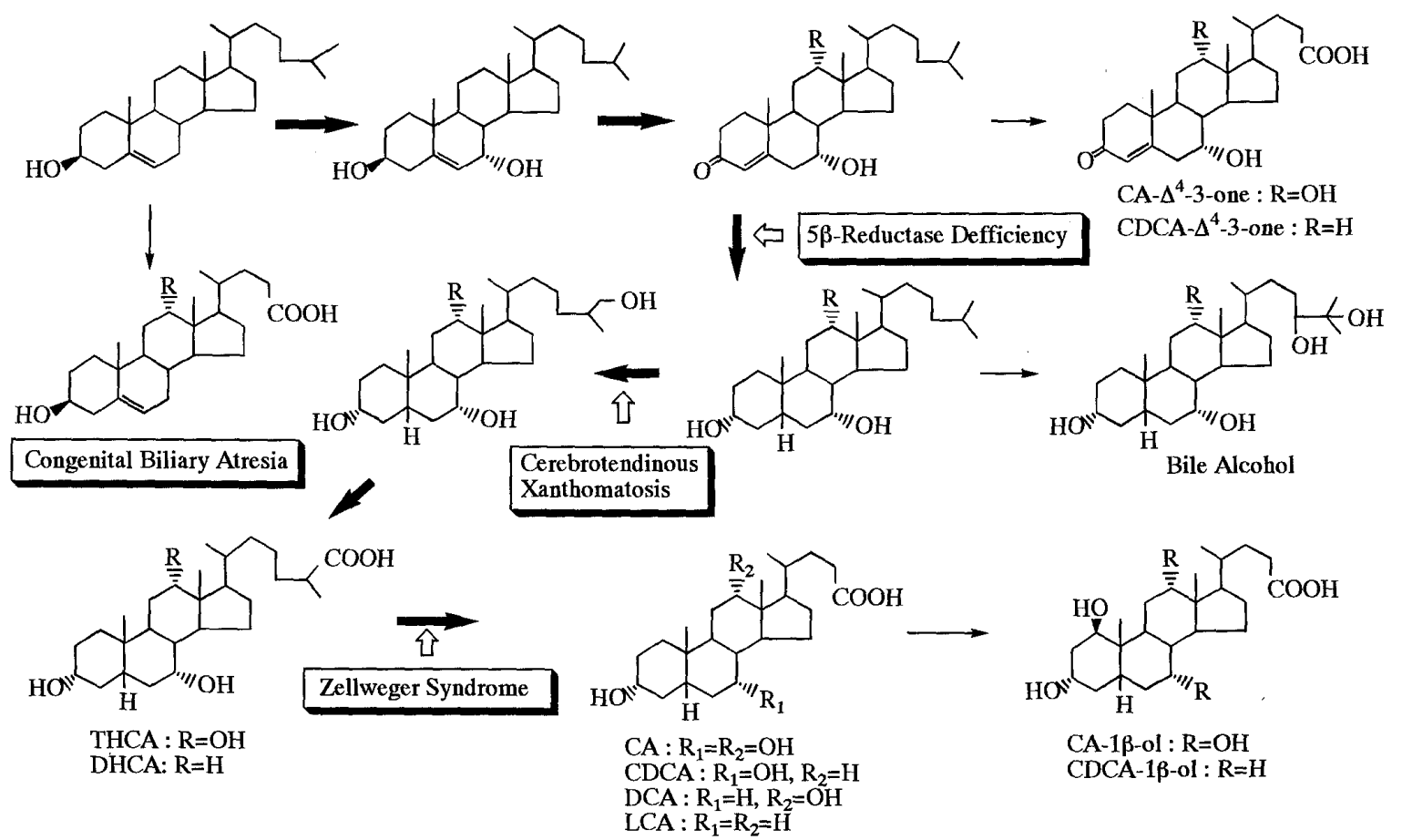

Fig. 18. Biosynthesis of Bile Acids and Congenital Disorders

1）新生児肝疾患——新生児期の肝胆道疾患による胆汁うっ滞患者の体液中には総胆汁酸量 が増大し, 当然ながら尿中の胎児性胆汁酸も高值を示すので, ${ }^{38,39)}$ 肝疾患の病態解析における 胆汁酸組成の動態は重要な診断指標になるものと思われる.

木村ら（久留米大）は肝内胆道不形成及び新生児肝炎による胆汁うっ滞患者に P-450 の酵素 誘導剤であるフェノバルビタールを投与して尿中胆汁酸の組成を検討したところ， $1 \beta$-水酸化 胆汁酸の生成が促進されて胆汁酸の尿排泄を增大し, 胆汁うっ滞の明らかな解消が認められ た. ${ }^{40,41)}$

一方，大菅ら（筑波大）は成人肝胆道疾患患者の体液中における胎児性胆汁酸の動態につい て検討したところ, 胆汁うっ帯により血液中胆汁酸が増量するので，成人の場合も胆汁うっ滞 時には，胎児-新生児期と同様に水酸化酵素が活性化されて，1 $1 \beta$-又は $6 \alpha$-水酸化により胆汁酸 の水溶性を増して尿中に排泄されることを認めた. ${ }^{42-45)}$

以上の結果を併せ考えるとき，このような水酸化は新生児肝疾患や胆汁うっ滞時における胆 汁酸排泄の重要な生理機能として作動するものと理解される.

2）先天性胆汁酸代謝異常——近年，新生児一乳幼児医療の発展による死亡率の低下に伴い，

Fig. 18 に示すように胆汁酸生合成における多くの先天性代謝異常症が見出されている。 しか し, その発症機序については不明な点が多く残され, 胎児一新生児期の胆汁酸の生合成並びに体 内動態の解明と共に, 各疾患の病態解析法について早急に検討する必要がある.

先天性胆道閉鎖症 (Congenital biliary atresia) は, 生れつき胆道が閉塞されて胆汁の流出が阻 害され，重篤な胆汁うっ滞を起こすので早期発見，手術治療の必要がある. 牧野ら（旭川医大） は本症患児尿中から $\Delta^{5}-3 \beta$-ol を見出し, ${ }^{46)}$ 著者らは GC-MSによる定量法を確立している が, ${ }^{17)}$ 秦ら (北海道大) と協力して, 本症の手術前後における血中 $1 \beta$-水酸化胆汁酸の測定を行 い，その動態解析により手術後経過の診断に適用できることを報告した. ${ }^{47-49)}$ また，本邦初の 生体肝移植（島根医大）に際してドナーとリシピエントの血液, 尿中の胆汁酸の分析により肝 


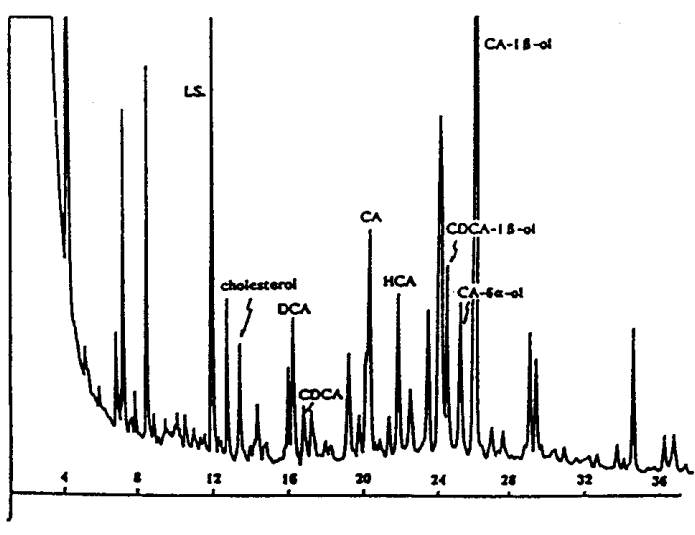

Healthy Neonate

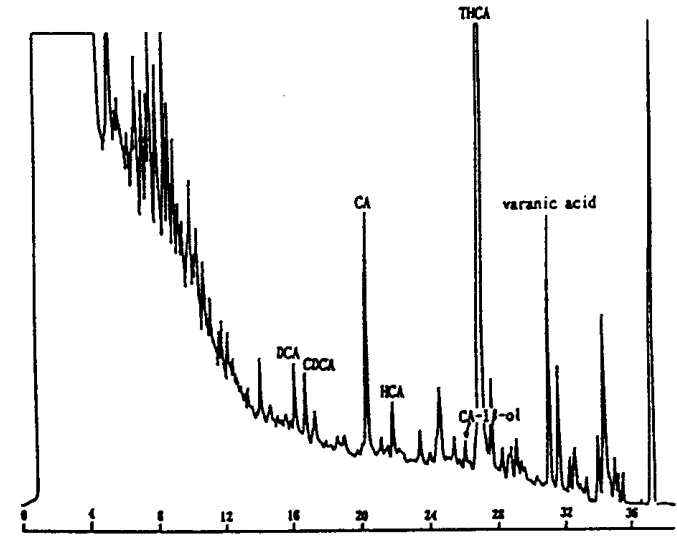

Zellweger Syndrome

Fig. 19. Capillary GC of the Me-DMES Derivatives of Bile Acids and Biosynthetic Intermediates in Urine of Healthy Neonate and Patient with Zellweger Syndrome

機能を検査したところ, 当然ながら胎児性胆汁酸は検出されなかったが, 移植肝は正常に機能 していることが示された. さらに後述するように胎児性胆汁酸を指標とする先天性胆道閉鎖症 のマススクリーニング法の開発が急がれている.

脳腱性黄色腫症 (Cerebrotendinus xantomatosis) は，胆汁酸生合成における 26-水酸化酵素の 欠損による先天性代謝異常症である．本症は，穂下やMosbach らにより広く研究され，体内に 種々の胆汁アルコールを蓄積することが明らかにされている. 最近, 少量ながら $1 \beta$-位に水酸 化された $\mathrm{C}_{22^{-}}, \mathrm{C}_{23}$ 胆汁酸が尿中に排泄されることを認めている. ${ }^{50)}$

さらに, Zellweger 症侯群は, ペルオキシゾームの欠損により胆汁酸生合成における $\beta$-酸化が 阻害され, 生合成中間体である $\mathrm{C}_{27}$-胆汁酸が尿中に排泄される先天性代謝異常症である. 各種 の生合成中間体の標品を化学合成し, キャピラリー GCによる $\mathrm{C}_{27}$ 胆汁酸の微量定量法を開発 した. ${ }^{51)}$ 生合成中間体である $3 \alpha, 7 \alpha, 12 \alpha$-trihydroxy- (THCA), $3 \alpha, 7 \alpha$-dihydroxy-5 $\beta$-cholestan-26oic acid (DHCA) 及び他の胆汁酸の組成は, Fig. 19 に示したように健常児の場合とは大きく異 なるので, 胆汁酸の測定による簡便な確定診断法を田沢ら（秋田大）と協力して開発して臨床 に適用した。

最近，新生児期に高チロジン血症 I 型類似の胆汁うっ滞から肝硬変に至り，乳児期に肝不全 で死亡した症例が木村ら（久留米大）により見出され，本症患者尿中には健常児に見られない 3-オキソ不飽和胆汁酸 (CDCA- $\Delta^{4}-3$-one, CA- $\Delta^{4}-3-$ one) が多量に存在することを認めた. ${ }^{53-55)}$ 次いで同様な症例が各地で見られ，著者らの分析例であ既に 10 例を超えているので, 全国的に はかなり多くの患者が存在するあのと思われる，小児科で肝疾患の診断に汎用されるは $3 \alpha-$ hydroxysteroid dehydrogenase による酵素法では 3-オキソ不飽和胆汁酸が測定されず，上記疾患 は胆汁うっ滞を呈しながら総胆汁酸量は低值を示すので, 本症の診断には極めて不適確な方法 と言える. 3-オキソ不飽和胆汁酸は Fig. 18 に示したようにコレステロールから胆汁酸生合成に 打ける中間体の $\alpha \beta$-不飽和ケトンが還元されることなく，側鎖が $\beta$-酸化されて $\mathrm{C}_{24}$ カルルボン酸 を生成したものと考えられるので，本疾患は 3-oxo- $\Delta^{4}$-steroid $5 \beta$-reductase の欠損による先天代 謝異常と推論される.オキソ不飽和胆汁酸の体内動態及び生成機序を明らかにするため, 標品 を化学合成して GC-MS により同定した。これらの胆汁酸は酸や塩基に極めて不安定なため, 
安定なメトキシム誘導体として緩和な前処理法を確立したのち, SIM 法によるオキソ不飽和胆 汁酸の高精度の微量定量法を開発した.さらに本法を用いて本症患児の尿について胆汁酸組成 を検討した結果，健常児ではほとんど検出されない CDCA- $\Delta^{4}-3$-one: 28.2\%，CA- $\Delta^{4}$-3-one: $15.7 \%$ が高值を示した。 また, 抱合型胆汁酸の HPLCによる的確な微量分析法を開発し, 新生 児肝疾患, 特に本症患児の各種体液について胆汁酸の体内動態と病態との関係を検討して, 新 しい視点に立ちオキソ不飽和胆汁酸を指標とする新生児肝疾患の病態解析法を開発することが できた. さらに酵素免疫测定法にる本疾患の簡便かつ迅速な診断法について検討中である．ま た, 患者より得られた肝組織中の本酵素の活性を測定すると共に, 発現量について特異抗体を 用いるウエスタンブロット法により解析し，胆汁酸の動態解析の結果と対比しながら病態解析 を進めている.

1-5. 胆汁酸の免疫学的測定法の開発と先天性胆道閉鎖症のマススクリーニング 最近, 生体肝移植治療で注目されている先天性胆道閉鎖症は，本邦では出生児の 10000 人に 1 人の割 合で発生するが，不幸にも発見が遅れると肝硬変に進行し，肝移植による治療に限られるので 大きな社会問題となっている，したがって，本症の簡便，迅速なる診断法及びマススクリーニ ング法の開発が小児外科領域より強く要請されている．胎児性胆汁酸の酵素免疫測定法による 的確な微量分析法を開発して，先天性胆道閉鎖症の病態解析法を検討したのち，早期診断法並 びに出生後 5 日検診時における浸染血液乾燥濾紙を用いるマススクリーニング法の開発を試み た.

臨床医学への応用には GC-MS に代わる高感度, 特異的かつ簡便, 迅速な分析法が必要であ り, 特異性に優れる免疫学的測定法の確立を目的として立体化学的に検討し, ${ }^{55-58)}$ 酵素免疫測 定法を開発することとした．新生児期胆汁酸の主成分であるタウロ-CA- $\beta-\mathrm{ol}$ 診断指標とし て特異性の高い抗体を得るため, 各種の胎児性胆汁酸ハプテンについてウシ血清アルブミン (BSA) 蛋白結合体を調製し，これらを免疫抗原として家兔に免疫して検討した．特に本胆汁酸 の24-カルボキシル基にタウリン抱合型と側鎖長が同じ $\beta$-アラニンを導入したハプテンの BSA 結合体から得た抗血清の力価及び特異性について ${ }^{3} \mathrm{H}$-標識抗原を用いる RIA 法により検討し た. タウロ-CA- $\beta-\mathrm{ol}$ に対して特異性の高い抗血清の作成に成功し, ${ }^{125} \mathrm{I}$-及び ${ }^{3} \mathrm{H}$-標識抗原を用 いる放射免疫測定法を開発することができ た. ${ }^{59-61)}$

次に，西洋ワサビペルオキシダーゼを標識酵 素とする 2 抗体法により酵素免疫测定法を開発 し, 本抱合型胆汁酸の体内動態について検討し た.この酵素免疫測定法に基づき，第 2 抗体之 してヤギ抗ウサギIgG抗体をマイクロタイ タープレートに固相化する ELISA 法 (EnzymeLinked Immunosorbent Assay) を開発した. ${ }^{62-64)}$ 多数の検体処理が可能な早期診断法として本法 を新生児 5 日検診時の浸染血液乾燥濾紙に適用 し，マススクリーニング法について検討した。 先天性胆道閉鎖症患児の尿及び浸染乾燥血液濾 紙による臨床診断の可能性を示すことができた (Fig. 20). 本法を新生児の生後 5 日又は 30 日

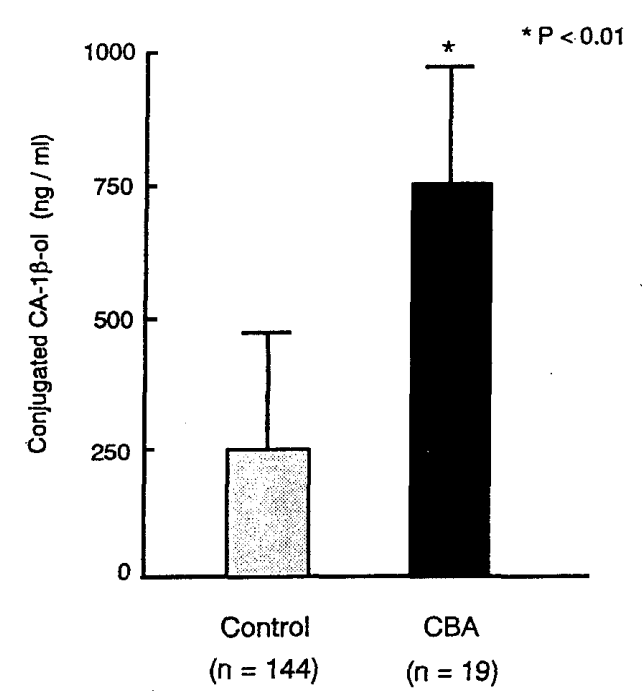

Fig. 20. Conjugated CA-1 $\beta$-ol Levels in Dried Blood Discs of Normal Neonates and Patients with Congenital Biliary Atresia 
検診時におけるマススクリーニングへの展開が，松井ら（自治医大）により進められている.

\section{2. ステロイドホルモン代謝成分の分析に関する研究}

胆汁酸の他にも生体内に存在する微量のステロイドホルモンについて, 標品を合成して化学 構造を明らかにしたのち, 高性能分析法を開発して臨床化学研究に適用したので, その概略を 述べる.

2-1. エストロゲンの分析と代謝エストロゲンは, 卵胞ホルモンと呼ばれる一群の芳香 族ステロイドホルモンである. 最あ生理活性の強いエストラジオールの免疫学的測定法につい て検討した．黑澤らは $\beta$-ケトスルホキシドを利用するエストロゲンの全合成法を開発している ので, ${ }^{65)}$ Fig. 21 に示すようにエストロゲンの C-11 又は 12 位にカルボキシル基を導入し, ${ }^{66-68)}$ これをハプテンとして BSA との結合体をウサギに免疫したところ，12 $\beta$ 位を架橋部位としたと き最む特異性の高い抗血清が得られた。これを用いてェストラジオールの放射免疫測定法を開 発することができた. ${ }^{69,70)}$

他方，エキリンは補充療法ホルモン剂として利用され， B 環に不飽和結合を有するエキンエ ストロゲンである，その代謝成分と考えられるカテコールエストロゲンやエキレニンは極めて 不安定で標品の合成が困難なため，その代謝経路については不明のまま残されていた。 上記と 同様な方法により標品を化学合成して, ${ }^{71,72)}$ 電気化学的検出 HPLCによる微量分析法を確立 し，エキンエストロゲンの代謝機構を解明することができた. ${ }^{73)}$

2-2. 副腎皮質ホルモンの分析と先天代謝異常の病態解析 原発性アルドステロン症は副 腎皮質過形成により発症し，早期に腫瘍を切除すれば治癒するので，的確な診断法の開発が要 請されている. 新規腫瘍マーカーとして 18-水酸化コルチゾール及びその代謝産物と推定され

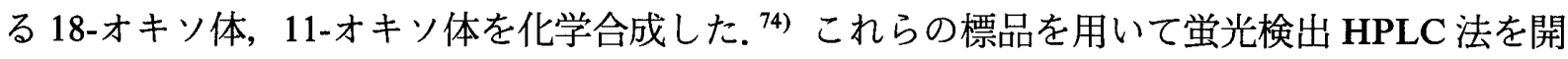
発し, ${ }^{75,76)}$ 本症患者の手術前の尿中には 18-水酸化コルチゾールが大量に排泄され, その代謝産 物あ認められた. しかし，手術後は健常レベルにまで低下することが確認された．さらに，本 疾患のマススクリーニング法の開発を目的としてモノクローナル抗体を作成した. 類縁ステロ イド化合物とはほとんど交差反応性を示さず，特異性に優れる酵素免疫測定法を開発すること ができた. ${ }^{77,78)}$ 本疾患の病態解析に応用し Table 5 に示す結果を得たので，本法は簡便なマス

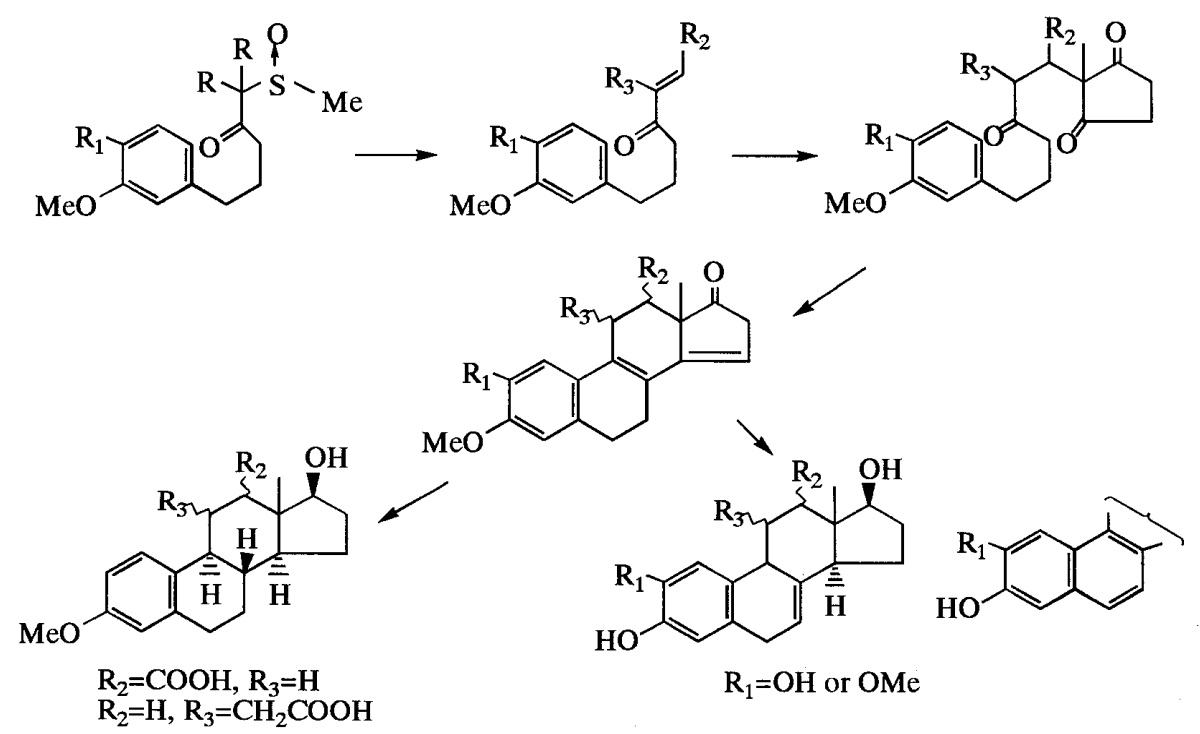

Fig. 21. Synthesis of 12-Carboxylated and Equine Estrogens 
Table 5. Urinary 18-Hydroxycortisol Excretion in Patients with Primary Aldosteronism

\begin{tabular}{lcccc}
\hline \hline & $n$ & \multicolumn{3}{c}{18 -Hydroxycortisol in urine } \\
\cline { 3 - 5 } & & $n$ nmol/1 & nmol/24h & nmol/g creatinine \\
\hline Primary aldosteronism & 8 & $1455 \pm 796^{a) *}$ & $2526 \pm 1942^{*}$ & $2878 \pm 1513^{*}$ \\
Before adrenalectomy & & $(728-2249)^{b}$ & $(836-7460)$ & $(1881-3804)$ \\
& 7 & $206 \pm 140$ & $254 \pm 93$ & $458 \pm 198$ \\
After adrenalectomy & & $(61-526)$ & $(135-386)$ & $(275-688)$ \\
& 40 & $212 \pm 140$ & $325 \pm 206$ & $381 \pm 241$ \\
Control & & $(21-516)$ & $(26-696)$ & $(26-1003)$ \\
\end{tabular}

a) Mean \pm S.D. $b)$ Range. ${ }^{*} p<0.001$ vs. corresponding control value.

スクリーニング法として適用できることが判明した.

おわりに

著者は, 当初よりステロイドの分析化学に関する基礎研究に従事し，生体内や天然物中のス テロイド配糖体の構造解析及び定量法の研究を行い，新規活性成分を見出して，その化学構造 を明らかにした。 スズラン花のステロイド成分から水溶性配糖体の分離にゲル濾過法を導入 し，強心配糖体の他に新規ステロイドサポニンの 7 種を単離した。そ糖部構造の解析に GC を導入して，効果的な糖類の分離定量法を開発し研究を推進することができた．また，先に述 ベた胎児性胆汁酸と同様に，奇しくも $1 \beta$-位が水酸化された新規ステロイドサポゲニンを見出 して構造解析を行い, ${ }^{79,80)}$ さらにステロイドの生体内水酸化のモデル反応について研究を行っ た.これらの研究は後の胎児性胆汁酸の研究に際し, 基礎研究として大きく寄与したものと考 える.

ここまで述べた研究は，薬学が永年培ってきた有機化学及び分析化学を駆使して的確な微量 分析法を開発することにより，全く未開拓の分野であった胎児一新生児期における胆汁酸代謝 の研究を進めることができた．また, 臨木医学の各研究室との密接な研究協力により, 薬学-周 産期医学の境界領域における研究を発展させることが出来たことは，著者にとって大きな喜び である.さらに医療の発展に貢献できる基礎研究をより一層展開して行きたいむのと考えてい る.

謝辞 本研究は, 北海道医療大学（旧東日本学園大学）薬品分析化学教室における池川繁 男助教授 (現東北大学), 黒澤隆夫助教授, 馬原礼二郎講師をはじめ教員, 院生並びに学生の努 力の賜であり, 多数の臨床医学共同研究者の御理解と御支援によるあのと深く感謝の意を表し ます。 また, 終始御指導, 御鞭撻を賜りました北海道大学名誉教授木村道也, 東北大学名誉教 授南原利夫の両先生をはじめ多くの同学の方々に心から感謝致します.

\section{引用 文 献}

1) 木村道也, 藤間貞彦, 吉沢逸雄, 分析化学, 23, 1100 (1974).

2) 藤間貞彦, 池川繁男, 黒澤隆夫, ぶんせき, 1988, 183.

3) Almé B., Bremmelgaard A., Sjövall J., Thomassen P., J. Lipid Res., 18, 339 (1977).

4) Back P., Walter K., Gastroenterology, 78, 671 (1980).

5) Strandvik B., Wikström S.-Å., Eur. J. Clin. Invest., 12, 301 (1982). 
6) Tohma M., Mahara R., Takeshita H., Kurosawa T., Ikegawa S., Nittono H., Chem. Pharm. Bull., 33, 3071 (1985).

7) Tohma M., Mahara R., Takeshita H., Kurosawa T., Ikegawa S., Chem. Pharm. Bull., 34, 2890 (1986).

8) Kurosawa T., Mahara R., Nittono H., Tohma M., Chem. Pharm. Bull., 37, 557 (1989).

9) Yoshimura T., Mahara R., Kurosawa T., Ikegawa S., Tohma M., Steroids, 58, 52 (1993).

10) Tohma M., Mahara R., Takeshita H., Kurosawa T., Steroids, 48, 331 (1986).

11) Dumaswala R., Setchell KDR., Zimmer-Nechemias L., Iida T., Goto J., Nambara T., J. Lipid Res., 30, 347 (1989).

12) Kurosawa T., Nomura Y., Mahara R., Yoshimura T., Kimura A., Ikegawa S., Tohma M., Chem. Pharm. Bull., 43, 1551 (1995).

13）黑沢隆夫，野村幸広，吉村昭毅，村井 毅，馬原礼二郎，藤間貞彦，分析化学， 44, 777 (1995).

14) Goto J., Hasegawa M., Kat H., Nambara T., Clin. Chim. Acta, 87, 141 (1978).

15) Tohma M., Nakata Y., Kurosawa T., J. Chromatogr., 171, 469 (1979).

16) Tohma M., Nakata Y., Yamada H., Kurosawa T., Nakagawa S., Makino I., Chem. Pharm. Bull., 29, 137 (1980).

17) Tohma M., Wajima H., Mahara R., Kurosawa T., Makino I., Steroids, 44, 47 (1984).

18) Tohma M., Takeshita H., Mahara R., Kurosawa T., Makino I., J. Chromatogr., 421, 9 (1987).

19) Mahara R., Takeshita H., Kurosawa T., Ikegawa S., Tohma M., Anal. Sci., 3, 449 (1987).

20) Miyara T., Shindo N., Tohma M., Murayama K., Biomed. Chromatogr., 4, 56 (1990).

21) Mahara R., Kurosawa T., Yoshimura T., Ikegawa S., Tohma M., Anal. Sci., 7, S.983 (1991).

22) Murai T., Mahara R., Suzuki M., Yoshimura T., Kurosawa T., Tohma M., J. Mass Spectrom. \& Rapid Commun. Mass Spectrom., 1995, S205.

23) Murai T., Mahara R., Kurosawa T., Kimura A., Tohma M., J. Chromatogr. B., in press (1996).

24) Ikegawa S., Hirabayashi N., Yoshimura T., Tohma M., Maeda M., Tsuji A., J. Chromatogr., 577, 229 (1992).

25) 吉村昭毅, 黒沢隆夫, 池川繁男, 藤間貞彦, 分析化学, 44, 865 (1995).

26) Goto J., Saito M., Chikai T., Goto N., Nambara T., J. Chromatogr., 273, 289 (1983).

27) Ikegawa S., Yoshimura T., Ito K., Kurosawa T., Tohma M., Anal. Sci., 11, 91 (1995).

28）藤間貞彦，黑澤隆夫，薬物動態，4, 607 (1989).

29) Obinata K., Nittono H., Yabuta H., Mahara R., Tohma M., J. Pediatr. Gastroentrol. Nutr., 15, 1 (1992).

30) Kimura A., Yamakawa R., Ushijima K., Fujisawa T., Kuriya N., Kato H., Inokuchi T., Mahara R., Kurosawa T., Tohma M., Hepatology, 20, 819 (1994).

31） 日向平明, 荒島真一郎, 馬原礼二郎, 藤間貞彦, 中島健夫, 服部 司, 我妻義則, 秦 温信, 臨床小児医学, 39, 223 (1991).

32) Gustaffson J., Anderson S., Sjövall J., Biol. Neonate, 47, 26 (1985).

33) Une M., Kisaka N., Yoshii M., Hoshita T., J. Biochem., 106, 501 (1989). 
34) Kurosawa T., Nakano H., Sato M., Tohma M., Steroids, 60, 439 (1995).

35) Kurosawa T., Sato M., Kikuchi F., Tohma M., Steroids, 61, 421 (1996).

36) Koibuchi Y., Yamada J., Watanabe T., Kurosawa T., Tohma M., Suga T., Chem. Pharm. Bull., 40, 446 (1992).

37) Une M., Inoue A., Kurosawa T., Tohma M., Hoshita T., J. Lipid Res., 35, 620 (1994).

38) Kimura A., Mahara R., Tohma M., Ushijima K., Yuge K., Ono E., Yamashita F., Clin. Chim. Acta, 185, 215 (1989).

39) Kimura A., Yuge K., Yukizane S., Kage M., Nittono H., Mahara R., Kurosawa T., Tohma M., J. Pediatr. Gastroenterol. Nutr., 12, 383 (1991).

40) Kimura A., Ushijima K., Kage M., Mahara R., Tohma M., Inokuchi T., Shibao K., Tanaka N., Fujisawa T., Ono E., Yamashita F., Acta Pediatr. Scand., 80, 381 (1991).

41) Kimura A., Ushijima K., Yamakawa R., Inokuchi T., Kage M., Mahara R., Tohma M., Kurume Med. J., 39, 105 (1992).

42) Shoda J., Mahara R., Osuga T., Tohma M., Ohnishi S., Miyazaki H., Tanaka N., Matsuzaki Y., J. Lipid Res., 29, 847 (1988).

43) Shoda J., Osuga T., Mahara R., Tohma M., Matsuura K., Tanaka N., Matsuzaki Y., Miyazaki H., J. Chromatogr., 488, 315 (1989).

44) Shoda J., Osuga T., Matsuura K., Mahara R., Tohma M., Tanaka N., Matsuzaki Y., Miyazaki H., J. Lipid Res., 30, 1233 (1989).

45) Honda A., Shoda J., Tanaka N., Matsuzaki Y., Osuga T., Shigematsu N., Tohma M., Miyazaki H., J. Chromatogr., 565, 53 (1991).

46) Makino I., Sjövall J., Norman A., Strandvik B., FEBS Lett., 15, 161 (1971).

47) 秦 温信, 佐々木文章, 阿部 毅, 浜田弘已, 田村 元, 内野純一, 角谷憲史, 馬原礼 二郎，藤間貞彦，肝臓，33, 819 (1989).

48) Hata Y., Uchino J., Sasaki F., Abe T., Koike Y., Alam S., Kakuya K., Nagano S., Mahara R., Tohma M., Pediatr. Surg. Int., 6, 309 (1991).

49) Hata Y., Sasaki F., Takahashi H., Hamada H., Tamura M., Ohkawa Y., Uchino J., Hyuga T., Mahara R., Tohma M., "Biliary Atresia,” ICOM Assoc. Inc., Tokyo, 1991, pp. 182-186.

50) Kuramoto T., Furukawa Y., Nishina T., Sugimoto T., Mahara R., Tohma M., Kihira K., Hoshita T., J. Lipid Res., 31, 1895 (1990).

51) Kurosawa T., Sato M., Kikuchi F., Tazawa Y., Tohma M., Anal. Sci., submitted (1996).

52) Kimura A., Ushijima K., Suzuki M., Tohma M., Inokuchi T., Kato H., Acta Paediatr., 84, 1119 (1995).

53）井上寿郎，木村昭彦，藤沢卓爾，芳野 信，加藤裕久，鈴木三佳子，村井 毅, 吉村昭 毅，黑澤隆夫，藤間貞彦，小児科，36, 101 (1995).

54）井上寿郎，木村昭彦，中嶋英輔，山下康博，藤沢卓爾，鈴木三佳子，黒澤隆夫，藤間貞 彦，日小児栄消病誌，9, 166 (1995).

55) Ikegawa S., Onodera H., Kinoshita J., Tohma M., Chem. Pharm. Bull., 36, 994 (1988).

56) Ikegawa S., Kinoshita J., Onodera H., Tohma M., Chem. Pharm. Bull., 33, 831 (1985).

57) 池川繁男，木下純子，許 真之，太田昌子，藤間貞彦，薬誌，108, 979 (1988).

58) Ikegawa S., Kinoshita J., Takeshita K., Sato H., Tohma M., Chem. Pharm. Bull., 37, 2147 
(1989).

59) Ikegawa S., Murai T., Yoshimura T., Xu Z-Z., Tohma M., Chem. Pharm. Bull., 40, 701 (1992).

60) Ikegawa S., Murai T., Yoshimura T., Tohma M., Chem. Pharm. Bull., 40, 1835 (1992).

61) Ikegawa S., Murai T., Matsui A., Tohma M., Biol. Pharm. Bull., 17, 5 (1994).

62) Ikegawa S., Murai T., Nakamura K., Sakaguchi T., Tohma M., Anal. Sci., 9, 791 (1993).

63) Ikegawa S., Kinoshita A., Kido K., Murai T., Yoshimura T., Tohma M., J. Immunoassay, 17, 105 (1996).

64) Segawa T., Ooizumi T., Yoshimura T., Tohma M., Kamidate T., Watanabe H., Anal. Sci., 11, 581 (1995).

65) Kurosawa T., Tohma M., Oikawa Y., Yonemitsu O., Chem. Pharm. Bull., 26, 1533 (1978).

66) Kurosawa T., Tohma M., Chem. Pharm. Bull., 36, 4284 (1988).

67) Kurosawa T., Tohma M., Oikawa Y., Yonemitsu O., Chem. Pharm. Bull., 29, 2101 (1981).

68) Kurosawa T., Niitsu U., Tohma M., Chem. Pharm. Bull., 35, 585 (1987).

69) Ikegawa S., Niitsu U., Kurosawa T., Tohma M., Chem. Pharm. Bull., 33, 1154 (1985).

70) Ikegawa S., Itoh M., Murao N., Kijima H., Suzuki M., Fujiyama T., Goto J., Tohma M., Biomed. Chromatogr., 10, 73 (1996).

71) Ikegawa S., Kurosawa T., Tohma M., Chem. Pharm. Bull., 36, 2993 (1988).

72) Ikegawa S., Kurosawa T., Tohma M., Steroids, 55, 250 (1990).

73) Ikegawa S., Kinoshita J., Kurosawa T., Tohma M., J. Pharm. Sci., 76, s19 (1987).

74) Kurosawa T., Ikegawa S., Chiba H., Ito Y., Nakagawa S., Kobayashi K., Tohma M., Steroids, 57, 426 (1992).

75) Chiba H., Ito Y., Matsuno K., Kobayashi K., Kurosawa T., Ikegawa S., Mahara R., Tohma M., J. Chromatogr., 613, 132 (1993).

76) Kurosawa S., Yoshimura T., Kurosawa T., Chiba H., Kobayashi K., Koike T., Tohma M., J. Liquid Chromatogr., 18, 2383 (1995).

77) Chiba H., Ikegawa S., Kurosawa T., Yoshimura T., Ito Y., Matsuno K., Kobayashi K., Tohma M., J. Steroid Biochem. Mol. Biol., 46, 85 (1993).

78) Kohno H., Sato S., Chiba H., Kobayashi K., Ikegawa S., Kurosawa T., Tohma M., Clin. Biochem., 27, 277 (1994).

79) Kimura M., Tohma M., Yoshizawa I., Chem. Pharm. Bull., 15, 1204 (1967).

80) Kimura M., Tohma M., Yoshizawa I., Chem. Pharm. Bull., 15, 1713 (1967). 